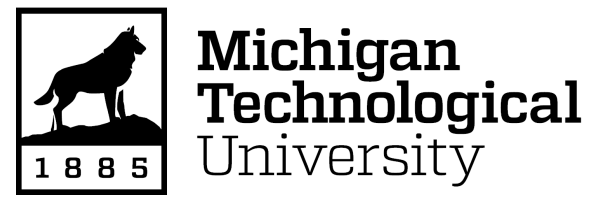

Michigan Technological University Digital Commons @ Michigan Tech

2016

\title{
Barriers to and Efficacy of Point-of-Use Chemical Drinking Water Treatment in Kolda, Senegal, West Africa
}

Barbara L. Michel

blmichel@mtu.edu

Copyright 2016 Barbara L. Michel

\section{Recommended Citation}

Michel, Barbara L., "Barriers to and Efficacy of Point-of-Use Chemical Drinking Water Treatment in Kolda, Senegal, West Africa", Open Access Master's Report, Michigan Technological University, 2016.

https://doi.org/10.37099/mtu.dc.etdr/284

Follow this and additional works at: https://digitalcommons.mtu.edu/etdr

Part of the African Studies Commons, and the Public Health Commons 
BARRIERS TO AND EFFICACY OF POINT-OF-USE CHEMICAL DRINKING WATER TREATMENT IN KOLDA, SENEGAL, WEST AFRICA

By

Barbara L. Michel

\begin{abstract}
A REPORT
Submitted in partial fulfillment of the requirements for the degree of MASTER OF SCIENCE

In Biological Sciences

MICHIGAN TECHNOLOGICAL UNIVERSITY

2016
\end{abstract}

(C) 2016 Barbara L. Michel 

This report has been approved in partial fulfillment of the requirements for the Degree of MASTER OF SCIENCE in Biological Sciences.

Department of Biological Sciences
Report Advisor:
Casey Huckins
Committee Member:
Mark Rouleau
Committee Member:
Dave Watkins
Department Chair: $\quad$ Chandrashekhar Joshi 



\section{ACKNOWLEDGMENTS}

Thanks to the country of Senegal, and especially the Sabaly family of Teyel, for showing me such amazing Teranga during my two years in your beautiful country.

Thanks to the United States Peace Corps for giving me the opportunity to live and work in another culture for 26 months. I learned more than I ever could have hoped, and I am better in a thousand ways as a result.

Thanks to Samba Kande for volunteering his time to help translate the surveys for this project, and for being the best Pulaar language coach in the world. Adiarama buy wonaa seeda.

Thanks to the inspiring community health care workers in Senegal, especially Abdoulaye Sabaly of Teyel, Tidiane Diao of Sare Meta, and Hamady Mballo of Koulinto. They tirelessly and thanklessly volunteer their time and limited resources trying to help their neighbors live better lives.

Thanks to the Peace Corps Volunteers who implemented the surveys necessary for this project: Morgan Brown, Laura Burmann, Annie Cleary, Jake Dunton, Alicia Gorina, Corin James, Jenn Lowe, Lexi Merrick, Nathan Rehr, Randi Rumbold, and LK Thams. This project could not have happened without you.

Thanks to Alicia Gorina, Nathan Rehr, and Jenna Dodson for helping me collect water samples in their communities, quantifying and recording the resulting data, and being great hosts while doing it.

Thanks to the PCMI community at Michigan Tech for keeping me sane as I struggled to make sense of readjustment to America, this report, and the 2016 presidential election season.

Thanks to my wonderful advisor, Casey Huckins, for his support and encouragement every step of the way, and to my committee for their guidance, support, and thoughtful critiques.

Thanks to my family and friends for their steadfast, baffling, completely illogical faith in me.

Thanks to you for reading this report. 

LIST OF FIGURES, TABLES, AND APPENDICES: $\ldots \ldots \ldots \ldots \ldots \ldots \ldots \ldots \ldots \ldots \ldots \ldots \ldots \ldots$

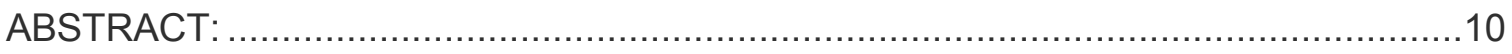

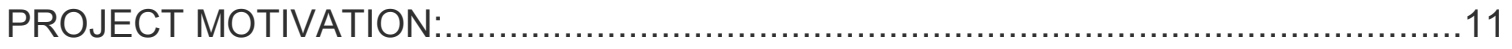

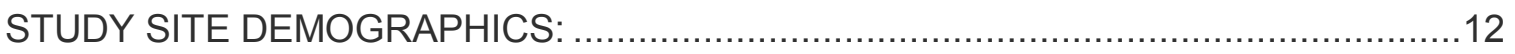

BACKGROUND OF WATER SITUATION IN KOLDA: .....................................13

POINT-OF-USE WATER TREATMENT STRATEGIES: .....................................15

DIFFICULTIES AND DRAWBACKS OF WATER TREATMENT USING BLEACH:......17

BLEACH TREATMENT IN THE WELL VS. THE LONDE: ..................................... 19

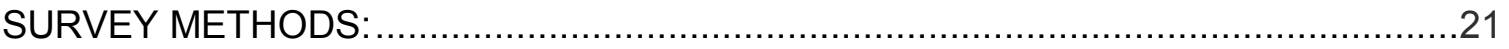

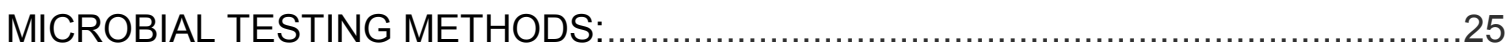

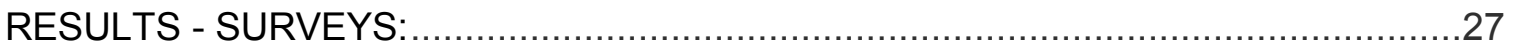

RESULTS - PETRIFILMS TM

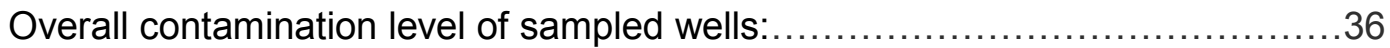

Contamination differences between lined and unlined wells:..................37

Contamination differences between treated and untreated londes:...............37

DISCUSSION:

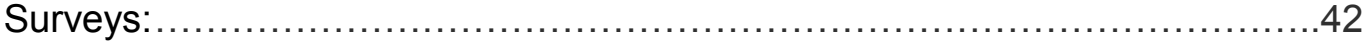

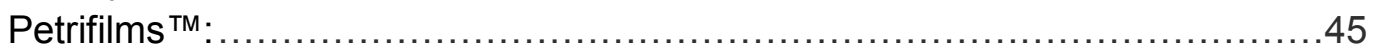

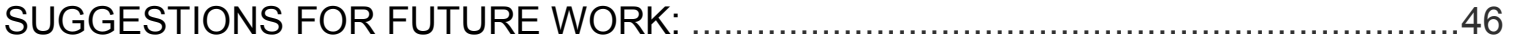

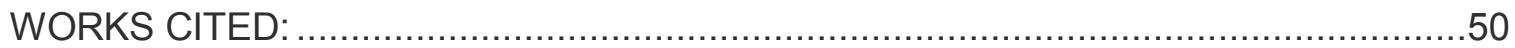

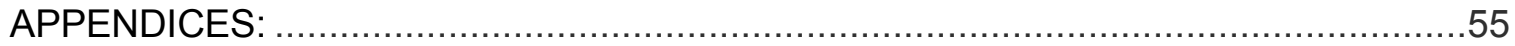




\section{LIST OF FIGURES}

Figure 1. A map showing the location of the study country (Senegal) ........................ 12

Figure 2. A map of Senegal showing the study region (Kolda) ................................ 12

Figure 3. A man digging a new well in Teyel, Kolda, Senegal .................................. 13

Figure 4. A boy using a rope and pulley to draw water from his family's well ............... 14

Figure 5. Water being poured through a cloth filter into a londe .............................. 14

Figure 6. A baby getting drinking water from her family's londe .............................. 15

Figure 7. A londe, the traditional clay water storage container used in the study site ... 18

Figure 8. A map of the Kolda region showing sites surveyed for this research ........... 24

Figure 9. The author pipettes $1 \mathrm{~mL}$ of water to Petrifilm ${ }^{\mathrm{TM}}$ media .............................. 25

Figure 10. Petrifilm ${ }^{\mathrm{TM}}$ media plates incubating at ambient temperature in Peace Corps Volunteer Alica Gorina's room in Dabo, Kolda, Senegal ................... 25

Figure 11. Two Petrifilm ${ }^{\mathrm{TM}}$ media plates, one showing no growth and one showing significant coliform and E. coli contamination ............................ 25

Figure 12. Breakdown of survey respondents by Treaters and Non-Treaters ............... 27

Figure 13. Breakdown of survey respondents by community size .............. 27

Figure 14. Do survey respondents think they can chemically treat their water with

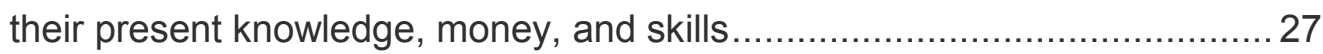

Figure 15. The amount of bleach that surveyed water Treaters reported using ........... 28

Figure 16. Times when Non-Treaters report using bleach for water treatment ............29

Figure 17. Disadvantages of chemical drinking water treatment with bleach .............. 30

Figure 18. What would make it easier for survey respondents to chemically treat

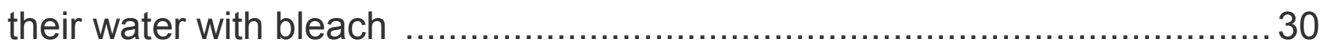

Figure 19. Difficulty to get materials needed to chemically treat water with bleach ........ 31

Figure 20. Who disapproves of you chemically treating your water with bleach? .......... 32

Figure 21. Advantages of chemical drinking water treatment with bleach.................... 33

Figure 22. Universal motivators - what the respondents said they desired more than anything else in life ................................................................. 33

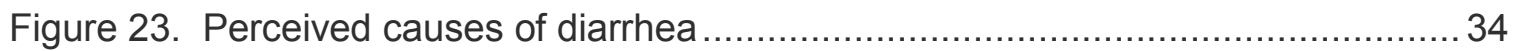

Figure 24. Likelihood of getting diarrhea from drinking untreated water ..................... 34

Figure 25. Contamination of sampled wells with $\mathrm{E}$. coli and coliforms ........................ 35

Figure 26. Comparison of E. coli and coliform contamination in cement-lined and unlined wells

Figure 27. Average coliform and E. coli growth in the wells and londes of Treaters and Non-Treaters

Figure 28. Coliform contamination at the source well and at the point of use (londe) for individual Non-Treaters

Figure 29. E. coli contamination at the source well and at the point of use (londe) for individual Non-Treaters.

Figure 30. Coliform and $\mathrm{E}$. coli contamination at the source well and the point of use (londe) for Treaters

Figure 31. Comparison of the amount of bleach used by both surveyed and sampled water Treaters 
Figure 32. Mural done by the author showing Danger Signs of Diarrhea

\section{LIST OF TABLES}

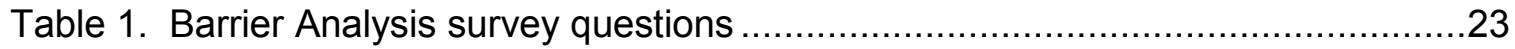

Table 2. Sites in Kolda surveyed for this research ................................................24

Table 3. Sites in Kolda where water sampling was conducted for this research............26

Table 4. Bleach added to Treaters' Iondes vs. coliform and E. coli counts ..................41

\section{APPENDICES:}

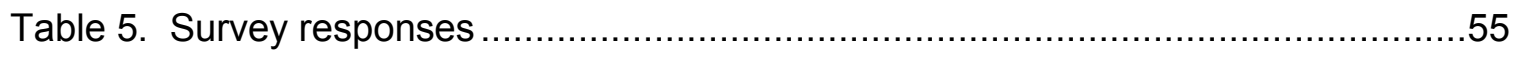

Table 6. Coliform counts for each sampled well and londe ....................................58

Table 7. E. coli counts for each sampled well and londe ...................................59 


\begin{abstract}
Hundreds of thousands of people throughout southern Senegal rely on well water as their drinking source, even though that water is frequently bacteriologically contaminated. Chemical treatment of water using a small amount of chlorine bleach has been shown to reduce its microbial load and to increase its safety for human consumption; however, the vast majority of people throughout West Africa do not disinfect their water before they drink it. This study was conducted in several communities in the Kolda region of Senegal. Individuals were surveyed on motivations and barriers towards bleaching or not bleaching their water, and then microbiological field testing was undertaken to examine the effectiveness of chemical treatment in the field. The open-ended qualitative surveys were designed with the Barrier Analysis framework and reached 46 people that regularly treat their water using bleach as per the World Health Organization (WHO) recommendation (Treaters) and 51 people that use untreated water (Non-Treaters). To accompany the surveys, $3 \mathrm{M}$ Petrifilms ${ }^{\mathrm{TM}}$ were used to test water from wells and household water storage containers (londes) to determine the efficacy of water treatment with bleach at the household (point-of-use) level. The microbial tests showed treated water was significantly less contaminated than untreated water in both coliform and Escherichia coli counts, even when the amount of bleach used for treatment was less than the dosage recommended by the WHO. Due to the efficacy of the method, continuation of the promotion of chemical drinking water treatment is recommended. A list of ten recommendations for future water treatment interventions in Kolda is provided in the discussion of this report. These recommendations were derived from survey results on motivations and barriers toward water treatment as well as on information gleaned from the available literature on the topic.
\end{abstract}




\section{PROJECT MOTIVATION}

I first became interested in this research while serving as a Peace Corps Volunteer in the Pulaar village of Teyel, Senegal, West Africa. Throughout my service, I observed that if weeks had passed since I had cleaned my wide-mouthed clay pot traditionally used for water storage (called a londe in Pulaar and a canari in French - see Figures 4 and 5), drinking water from that pot made me sick even though I had filtered it previously. This caused me to question the importance of storage on water quality, since it seemed like my filtered and previously safe-to-drink water had become recontaminated during storage. I did some preliminary research and found that many studies have been done in developing countries comparing water at the source to water at point-of-use (e.g. while being stored in a londe at home). It is both possible and common for water to become contaminated during storage, even if it was clean when collected (Wright 2004, Seib 2011, Mengistie 2013, Trevett 2005, Mellor 2013). For this reason, point-of-use water treatment is recommended by most development organizations.

There are several ways to treat water at point-of-use, which are reviewed in the "Pointof-Use Water Treatment Strategies" section of this report. Point-of-use water treatment has been shown effective in several published studies at both disinfecting water and at decreasing the burden of diarrhea (see review by Arnold, 2007).

Despite its benefits, most people throughout West Africa do not utilize a point-of-use water treatment method (Rosa 2010, McMahon 2013). As I asked around my village, I found that point-of-use treatment was very uncommon in my community, as well; however, some of my neighbors did treat the water before they drank it. Among the water Treaters, the water was most commonly disinfected using a small amount of chlorine bleach. Since bleach was so common, cheap, and readily available in my community, and because it seemed like the process was widely known (though seldom practiced) I decided to investigate some possible reasons why the Treaters treated their water, but the majority of the population chose to continue using untreated water. I constructed a survey using the Barrier Analysis framework (Kittle 2013) to explore hidden motivations or reasons for reluctance for water treatment. I also utilized 3M Petrifilms $^{\mathrm{TM}}$ to test for coliform and E. coli in londes and source wells to test the efficacy of the proposed treatment method in normal field conditions. I planned to use the findings to help future Peace Corps Senegal volunteers in the Kolda region better target future behavior change interventions. 


\section{STUDY SITE DEMOGRAPHICS}

This project was conducted in the West African nation of Senegal (Figure 1), in the region of Kolda. Kolda is located in the south of Senegal, separated from the capital city of Dakar by the nation of The Gambia (Figure 2).

The Kolda region contains roughly $5 \%$ of Senegal's population and $7 \%$ of its land area. Urbanization is progressing quickly in the Kolda region; between 2002 and 2016, city dwellers increased from $16 \%$ to $26 \%$ of the region's population (ANSD, 2013). The dominant ethnic group of Kolda is Pulaar (also known as Fulani), but there are also some isolated Mandinka villages. Other ethnic groups (Wolofs, Sarakoles, Sereers, and Jolas) can be found in urban areas (ANSD, 2013). In Senegal as a whole, $78 \%$ of the labor force participates in agriculture (CIA World Fact Book), but in Kolda villages nearly everyone helps in the fields in some capacity during the rainy season from July to October. Seventy-five percent of Kolda farms are small, consisting of only 1-5 hectares of land (ANSD, 2013). Millet, corn, peanuts, rice, and cotton all commonly grown, with some crops sold and some kept for personal consumption (ANSD,

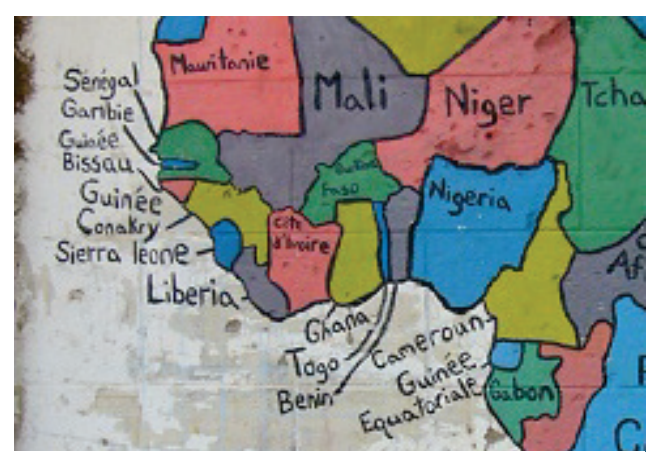

Figure 1 . The location of the study country (Senegal) in a map of West Africa. Senegal is directly west of southern Mali. Mural and photo credit: Barbara Michel

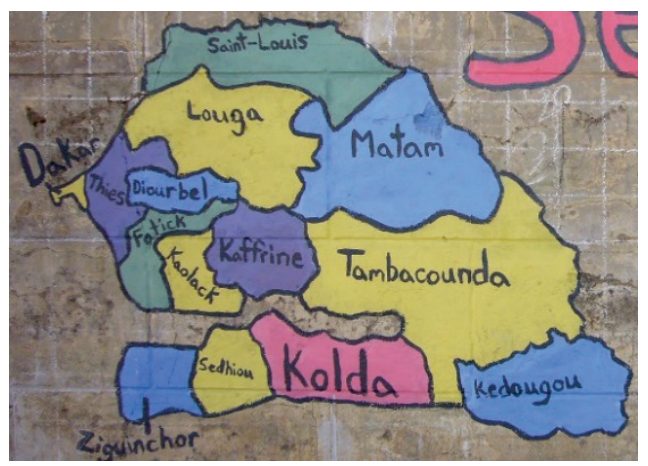

Figure 2. The location of the study region (Kolda) in Senegal. Kolda is in the south of the country. Mural and photo credit: Barbara Michel 2013). Animal husbandry is also an important part of Pulaar culture. In 2013, there were 461,870 cattle reported in the region (over half of the human population!) (ANSD, 2013), and goats, cows, and chickens frequently roam through both the cities and the villages.

Senegal as a whole has a $46.7 \%$ poverty rate (CIA world fact book) but that rate is higher in the Kolda region, which has $76.6 \%$ poverty - the highest in Senegal (ANSD, 2013). In Kolda, $72 \%$ of students attend elementary school and $48 \%$ attend middle school (ANSD, 2013). The over-15 literacy rate in the Kolda region is $43.7 \%$. The average birth rate in Senegal is 4.3 children per woman (CIA World Fact Book), and in Kolda it is 6.3 (ANSD, 2013). Kolda has the second-highest child-under-five mortality rate of any region in the country, with 145 deaths per 1000 live births (ANSD, 2012).

In 2013 , only $69.9 \%$ of the Koldan population had access to a safe water source within one kilometer (ANSD, 2013). The rest of the population, including everyone surveyed for this study, relies on wells classified as "unprotected" by the WHO as their water source. 


\section{BACKGROUND OF WATER SITUATION IN KOLDA}

Worldwide, great progress has been made in the past several years in the availability of safe drinking water. Millennium Development Goal Target 7.C (halving the world's population without access to safe drinking water) was met in 2010, five years ahead of schedule (UNICEF). Between 1990 and 2015, 2.6 billion people worldwide gained access to improved drinking water sources. In Senegal from 1990-2015, access to improved water sources increased from $60 \%$ to $79 \%(\mathrm{WHO})$.

Despite these remarkable gains, there are hundreds of thousands of people in Senegal who have not yet been reached by modern water systems. In Senegal, Kolda was the region most affected by lack of access to safe water in 2013 , with only $69.9 \%$ of the population having access to a safe water source within one kilometer (ANSD 2013).

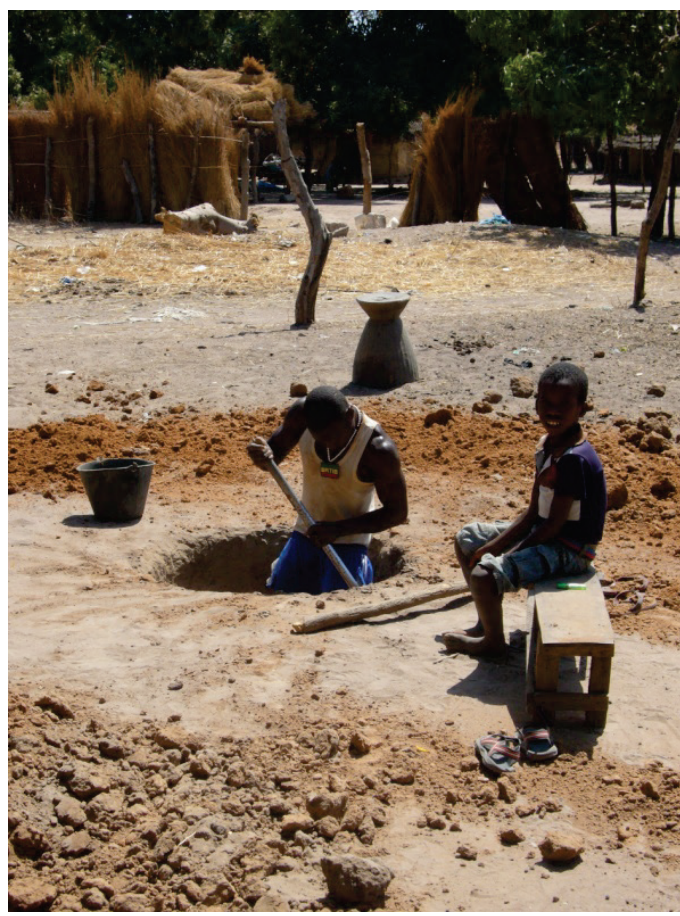

Figure 3. A man in Teyel, Kolda, Senegal digs a new well. Photo credit: Barbara Michel

Those in Kolda without a safe water source (around 200,000 people) rely predominantly on uncovered dug wells. Depending on the water table, wells can be as shallow as 7-10 meters, or as deep as 30+ meters. Some wells, especially the deeper ones, are fully lined with cement, but the majority are not lined - they are simply dug by hand until the water table is penetrated (Figure 3 ), then deepened if they start to dry up. Most wells have a 3-4-foot concrete wall surrounding the hole (Figure 4), but the wells are usually not kept covered. Because the water is not protected from windblown contaminants or bird or bat droppings, uncovered wells are classified as "unprotected" water sources by the WHO. Water is drawn from dug wells with a rope and bucket, or occasionally with a well bag. The rope and bucket are operated by hand, usually with the assistance of a metal pulley (Figure 4).

Microbial contamination of wells is common. In Luby's (2006) study in Bangladesh, 56 of 127 wells (44\%) contained fecal coliforms, and in Colombatti's (2009) study in GuineaBissau, all of the 12 sampled water sources were microbiologically contaminated. Of the 11 wells sampled for this study, all were shown to contain either coliform or E. coli (Figure 24). Expensive and time-consuming modernization of a traditional well (through covers or pumps) does increase the quality of the water at the source; however, since the water is so easily contaminated after collection, these costly rehabilitation projects do not have a significant impact on water quality at the point-of-use level (Gelinas 1996). 


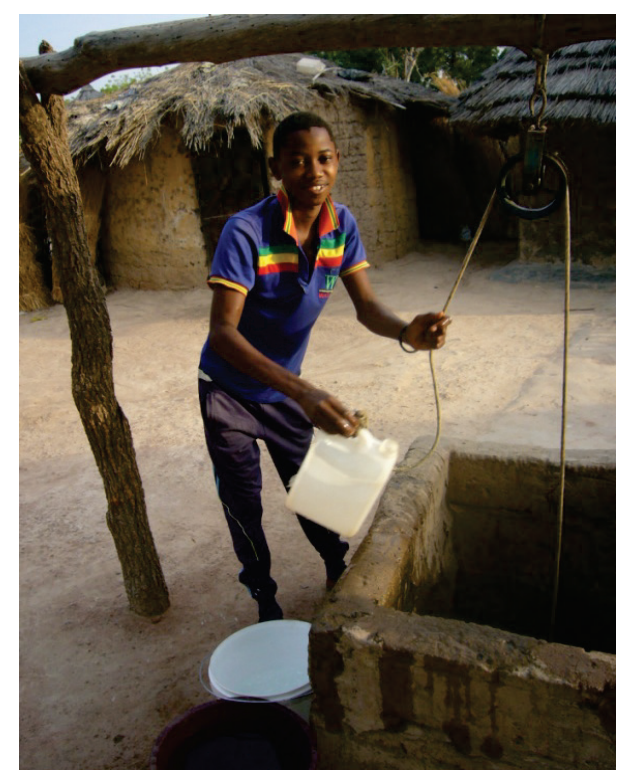

Figure 4. A boy uses a rope and pulley to obtain water from a well. Photo credit: Barbara Michel

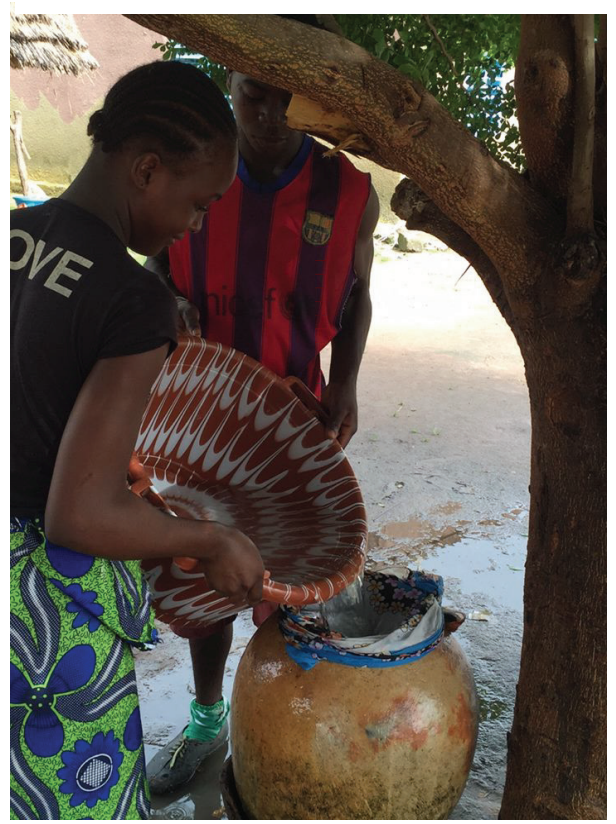

Figure 5. Water is poured through a layer of cloth into a traditional wide-mouthed clay storage container (called a londe in Pulaar, the local language of the study site.) Photo credit: LK Thams
Unclean water can have severe health consequences. According to the CDC, unsafe water and inadequate hygiene and sanitation account for $88 \%$ of diarrheal cases worldwide each year. In 2013, $9 \%$ of officially reported deaths of children under 5 in Senegal were caused by diarrhea (UNICEF), but the true figure may be even higher than that, since some deaths go unreported and many official causes of death are listed as "undetermined." Furthermore, since malnutrition, measles, and pneumonia have all been shown to coexist with diarrhea, any officially reported deaths in those categories may be at least partially due to the presence of diarrhea in the child (Garenne 1990). In the Kolda region of Senegal, where this study took place, the childunder-five mortality rate is 21 times higher than in America, with 145 deaths per every 1000 live births (ANSD, 2012).

Children and adults in Senegal also face diarrhea risk in the form of occasional cholera outbreaks. In $2008,94 \%$ of the world's cholera was in subSaharan Africa (Cavallaro, 2011). During the last large outbreak in 2012, there were over 40,000 confirmed cases of cholera and over 800 deaths throughout West and Central Africa (Nossiter 2012). Cholera bacteria can be inactivated by any of the point-of-use water treatment methods discussed in this report.

Water often becomes contaminated during collection and pre-consumption storage (Wright 2004, Seib 2011, Mengistie 2013, Mellor 2013). In the Kolda region where this study took place, pointof-use treatment of water is not typical. Instead, empty londes are scrubbed with mango leaves and rinsed with a small amount of water. Next the water is drawn from a well (Figure 4), carried to the londe in a transfer bucket, and poured into the londe through 1 or more layers of cloth (Figure 5). The cloth is used to remove any visible particulate matter, such as leaves, insects, sand, etc. In between uses, the cloth used for filtering is usually kept near the londe, often placed on a tree branch or tucked into a ceiling beam. The efficacy of the cloth filter is divided in the literature. According to a study by Colwell et al (2003), simple cloth 
filtration significantly reduced the occurrence of cholera in Bangladeshi populations. Cloth filters provide a mesh size of $20 \mu \mathrm{m}$, and although most bacteria, viruses, and protozoa are smaller than that, cloth filtering can remove bacteria that are stuck to particulate matter in the water (Colwell 2003). Since cholera is usually associated with plankton in the water, filtering out the particulates can significantly decrease the presence of cholera in the water (Colwell, 2003). However, Trevett (2005) argues that because of the unhygienic conditions where the cloth filters are usually stored, the use of a filter might actually contaminate the water further, especially in such cases where the water is not turbid and there are few particulates to remove. In any case, the EPA recommends that filters for the treatment of water be sensitive enough to remove particles $1 \mu \mathrm{m}$ or less in diameter (EPA, 2005), so cloth filtering alone is not sufficient to provide truly clean water.

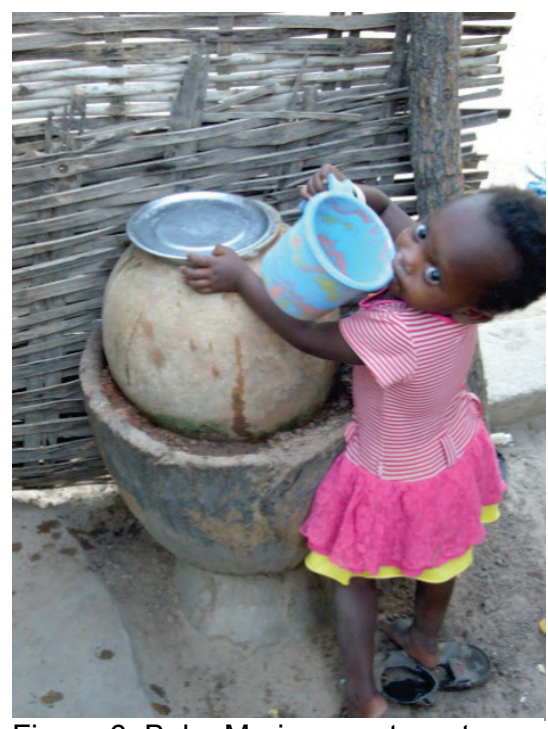

Figure 6. Baby Mariama gets water from her family's londe. Londes are used by every member of the family and water stored in them is usually not treated. Photo credit: Barbara Michel

After the water is poured through the cloth into the londe, no further treatment is usually undertaken, and the londes are utilized by all members of the family (Figure 6). At this point, the literature shows that it is common for the water's quality to decline through fingers soiled by fecal contamination, dirty drinking cups, windblown particles entering uncovered londes, or incubation of bacteria already present in the water (Trevett 2005, Mellor 2013).

Since it is so common for water from shallow dug wells to be contaminated and for previously safe water to become contaminated during storage, pre-consumption treatment of drinking water is necessary in this population. A metaanalysis by Arnold (2007) showed that point-of-use chlorine treatment reduced diarrhea in children in 9 out of 10 studies, and that adoption of practices leading to safe water could account for a $20 \%$ to $35 \%$ decrease in diarrheal disease. Therefore, an increase in people treating their water at point-of-use water could prevent diarrhea and save lives. 


\section{POINT-OF-USE WATER TREATMENT STRATEGIES}

Peace Corps Senegal encourages community health volunteers to pursue water treatment projects during their Peace Corps services. Peace Corps Senegal Standard Sector Indicator Data Sheet HE-057 states that safe water can be treated after collection by boiling for one minute, adding iodine or chlorine bleach, or using solar disinfection (also known as SODIS). My literature review showed that other water treatment methods are sometimes used in other areas of Africa, including clay or ceramic filters or deflocculant sachets (Arvai 2011). Of all these water treatment options, the only one I observed people using in Kolda was chlorine bleach. The others were all untenable for reasons outlined below.

\section{Boiling}

Because of its high specific heat, water takes a long time and a lot of fuel to boil. A water treatment study in Tanzania showed it can take six hours to obtain four liters of clean water, including time spent to gather wood, fetch the water, light the fire, and heat to boiling (Arvai, 2012). In Senegal, 90\% of cooking is done with wood (Practical Action Consulting, 2014); however, the promotion of boiling as a means of water treatment would likely be unattractive to overworked women, since it would mean more wood to gather and more fires to tend. This was the main complaint about boiling as a water treatment method in rural Kenya (Arvai 2012). Additionally, since deforestation is an important issue in Senegal (ANSD 2013), it is difficult to recommend the further depletion of trees when easier and more low-impact methods are available.

\section{SODIS}

Solar water disinfection involves placing a clear plastic water bottle full of source water in the sun for at least one day. The solar radiation disinfects the water. Although this method is simple and effective, there are some barriers preventing its widespread adoption. First, the villagers must wait a full day to get the water they need. Secondly, although plastic bottles are available for a low cost at markets (usually 25 CFA per bottle, about \$.05), they're difficult to maintain at the village level. The sun weakens the plastic, and rodents and insects can chew holes in them. Many households in Senegal consist of 10 or more people, and it is recommended that adults drink around 4 liters of water a day. Since solar disinfection only works with smaller bottles (1-1.5 L each), purchasing enough bottles and replacing the damaged ones might be an economic burden for some families.

\section{lodine Tablets or Ceramic Filters}

lodine tablets or tinctures can be added to water for an easy, safe, and quick treatment, but I did not see iodine available for purchase in Senegal when I lived there in 20142016. Ceramic or charcoal filters were also unavailable through local sources. 


\section{Aquatabs}

AquaTabs $^{\mathrm{TM}}$ are sometimes available in Senegal. Their active chemical is Sodium Dichloroisocyanurate and they work in much the same way as Sodium Hypochlorite (liquid bleach). There are advantages in using AquaTabs ${ }^{\mathrm{TM}}$ instead of bleach. Sodium Dichloroisocyanurate works in a wider $\mathrm{pH}$ range than Sodium Hypochlorite does, and it also has a much longer shelf life (Clasen, 2005). Since AquaTabs ${ }^{\mathrm{TM}}$ are sold as effervescent tablets, they are easier to dose with and less prone to spillage than liquid bleach is (Clasen, 2005). AquaTabs ${ }^{\mathrm{TM}}$ have been successfully used by NGOs and governmental programs in Senegal. In 2010, USAID distributed 62,000 AquaTabs ${ }^{\mathrm{TM}}$ at the Magal festival in Touba, Senegal, and that year was the first on record with no outbreaks of diarrheal disease (Gambrill 2013). Though AquaTabs ${ }^{\mathrm{TM}}$ show potential as a water treatment product, their availability in Senegal without the outside influences of development organizations is questionable. A 2016 USAID pharmacy audit showed that only one of 13 pharmacies visited had AquaTabs ${ }^{\text {TM }}$ in stock (Brunner, 2016). The audit also stated that water treatment materials experienced the most frequent stock-outs of any class of product in pharmacies (Brunner, 2016). During my two years in Senegal, I occasionally saw AquaTabs ${ }^{\mathrm{TM}}$ at government health structures and privately owned boutiques, though they were not as commonly available as liquid bleach is. Some evidence shows that AquaTabs may not be readily embraced by West African populations. In the West African country of Benin, two years of NGO-funded mass media marketing campaigns, advertisements, and giveaways of promotional and educational materials only raised the use of AquaTabs from 6-11\% of the target population (Inungu, 2016)

\section{Liquid Bleach}

In contrast to all these methods, bleach is cheap, easy, effective, and widely available throughout the country. Adoption rates of treating water with bleach at the point-of-use level are low (estimated to be $5 \%$ of the population or less based on data collected from other West African countries in Rosa 2010 and McMahon 2013). However, bleaching is the only chemical water treatment method I observed actually being employed in my community. When used correctly, bleach chlorination kills most microbes and offers residual protection to prevent recontamination for up to 24 hours (Makutsa, 2001). Bleaching londes is easy. After a small amount of bleach (8-16 drops per gallon, or 2.11$4.22 \mathrm{~mL} / 20 \mathrm{~L}$ ) is added, the water simply sits for a half-hour before it is consumed. If a $20 \mathrm{~L}$ londe is treated with $3 \mathrm{~mL}$ of bleach a day, a $500 \mathrm{~mL}$ bottle of bleach will last for 166 refills. There is no special equipment that needs to be purchased or repaired. Although bleach has limited efficacy against cryptosporidium, toxoplasma, giardia, and entamoeba (Steiner 1997, Minz 2001, Arnold 2007, CDC 2012), it is very effective against bacteria and viruses, including cholera, E. coli, Salmonella, and Shigella (CDC, 2012). Several studies have vouched for its efficacy, showing that adoption of bleach treatment practices causes a significant decrease in the prevalence of diarrhea in the population (see review by Arnold 2007). 


\section{DIFFICULTIES AND DRAWBACKS OF CHEMICAL WATER TREATMENT USING BLEACH}

Although bleach is the water treatment method most likely to be feasibly implemented in the Kolda region (see "Point of Use Water Treatment Strategies" section), it is not a perfect product. The downsides of using bleach as a water treatment are outlined below.

\section{Product quality:}

- The bleach available in developing countries can be difficult to accurately dose with. Commercially produced bleaches intended for household use have a wide range in concentration (usually from 1-9\%), so unless the concentration of a brand of bleach is known, it cannot be known precisely how much bleach is needed. A study of locally available bleaches in developing countries showed that only $75 \%$ of bleaches had a concentration listed on the bottle, and even if the concentration were listed, average error between advertised and measured concentration was 35\% (Lantagne, 2009). The Senegalese brand, MADAR, does have a concentration listed on the bottle (8\%), but in Lantagne's study it was found that only $25 \%$ of sampled bleaches were within $10 \%$ of their advertised concentration (Lantagne, 2009). With such variation between bleaches and unreliability of advertised concentrations, it would be easy to have too much or too little active product.

- Chlorine can become deactivated during storage and most bottles are not stamped with a date of production or an expiration date.

- Some bleaches may have harmful fragrances or additives added (Lantagne, 2009).

\section{Dosing problems:}

- Londes, the traditional wide-mouthed jars used to hold drinking water, are custom-made out of clay (Figure 7). They usually have a capacity of around $20-25 \mathrm{~L}$, but can be larger or smaller. Since there is natural variation in any handmade product, it is impossible to know their exact capacity unless it is measured, which is difficult to do in a resource-poor environment. Therefore, it can be tricky to know exactly how much water needs to be treated, and exactly how much bleach is needed to do it.

\section{Inefficacy against some microbes:}

- Since the oocysts of cryptosporidium and giardia are thick and resistant to chlorine, bleach might not be

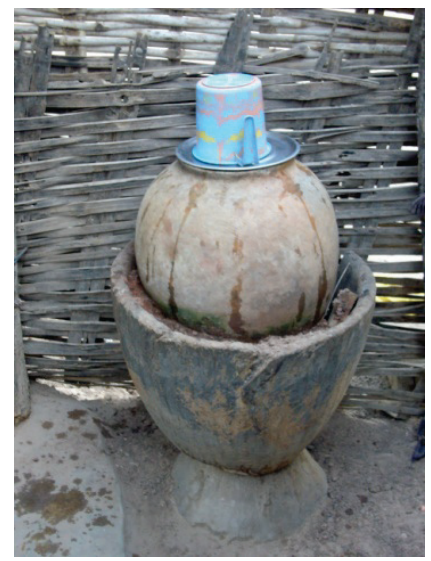

Figure 7. A londe, the traditional wide-mouthed clay pot used for water storage in the study site. Photo credit: Barbara Michel enough to adequately disinfect the water when used at the WHO-recommended dosage range and exposure time (Steiner 1997, Minz 2001, CDC 2012). Therefore, depending on what pathogens are in the contaminated water, 
household bleach treatment might not be adequate to render the water safe to drink.

\section{Dangers:}

- If too much chlorine is used, it can make the water distasteful. If it doesn't taste good, people may be more likely to abandon the intervention and to continue to drink unsafe water. Indeed, $11 \%$ of survey respondents for this study listed "Bad Taste" as a disadvantage to using bleach for point-of-use water treatment (Figure 17). However, $4 \%$ of respondents listed "Good Taste" as an advantage to the intervention (Figure 21), so it's possible that the slight chlorine taste could actually be preferable to some people. While doing microbial testing as part of the research for this report, I sampled the water of several water Treaters and found that a dosage of $1 \mathrm{~mL}$ was imperceptible, a dosage of 2-4 $\mathrm{mL}$ was noticeable but not unpleasant, and a dosage of $11 \mathrm{~mL}$ was extremely distasteful (Table 4). The WHO recommended dosage for a $20 \mathrm{~L}$ londe is $2.11-4.22 \mathrm{~mL}$.

- There is a risk of accidental bleach poisoning, though this risk is small. Harley (1997) examined the 41,000 bleach exposures reported to the American Association of Poison Control Centers in 1993. Of these, only three were fatal two suicidal adults and a 2-year-old asthmatic child who inhaled too many fumes. It is estimated that a person would have to drink $300-500 \mathrm{~mL}$ of household bleach for a lethal effect, which is too much for anyone to drink accidentally due to bleach's strong negative taste and smell (keep in mind a 12-oz can holds 355 $\mathrm{mL}$ ). In Harley's study, not only were there no deaths due to accidentally ingesting bleach, there were also no long-term conditions linked to any of the bleach exposures. Bleach solutions of less than $10 \%$ cause minimal damage. This includes all bleaches purchasable for household use in America, as well as the Senegalese brand Madar ${ }^{\mathrm{TM}}$, which has an advertised concentration of $8 \%$.

- Laboratory studies administering highly bleached water to mice and rats showed lowered liver, heart, brain, and kidney weights in the animals, and extremely high concentrations caused sperm abnormalities (WHO, 2004). All of these studies involved concentrations of bleach greater than the concentrations reportedly used by the Treaters in this study.

- A population-based, case-control study of chlorinated tap water's effects on humans showed an increased risk of bladder cancer amongst those who had consumed chlorinated water at least half their lives (WHO, 2004).

- Treating water with bleach can cause dozens of disinfection by-products (DBPs) which may cause an increased risk of cancer (Hrudey, 2009). Conservative DBP concentration threshold guidelines are enforced in large municipal water systems in developed nations, but resources for monitoring DBPs are not available in Kolda. DBP concentrations can be reduced by only treating water that contains a low amount of dissolved organic matter. 


\section{BLEACH TREATMENT IN THE WELL VS. IN THE LONDE}

Although using bleach as a point-of-use water treatment method is rare in Kolda, it is somewhat common for individuals in the population to pour bleach into the well directly. Of the 51 Non-Treaters surveyed for this research, only 9 (18\% of the Non-Treaters) said that they "never" used bleach as a water treatment method (Figure 16). Of the 11 wells sampled for bacteriological quality for this report, three had been bleached in the months preceding sampling (Table 2).

When wells are bleached, typically an entire $0.5 \mathrm{~L}$ or $1 \mathrm{~L}$ bottle is poured directly into the well when it is perceived that the water is "dirty." To be safe to drink, the WHO recommends bleach-treated water have measurable residual chlorine levels of .2-.5mg $\mathrm{L}^{-1}$ during non-epidemic periods, increasing to $1 \mathrm{mg} \mathrm{L}^{-1}$ during epidemics (WHO). When liquid bleach was added directly to the wells in Guinea Bissau (Rowe 1998), less than half the wells reached that WHO-recommended adequate chlorine level, and the chlorine lasted a median of only one day before dissipating. In Luby's 2006 study, zero of the 13 wells in Bangladesh treated with liquid bleach showed an adequate reduction in bacteria to be considered decontaminated.

Engineered pot chlorinators, meant to aid in the slow dissemination of chlorine crystals in the well, were also shown to be ineffective (Cavallaro et al, 2011). In Cavallaro's study in Guinea Bissau, the slow-release chlorine crystals were inactivated below the level of efficacy in only 72 hours. If slow-release crystals are inactivated so quickly, liquid bleach can be expected to be even more ephemeral.

Shock chlorination works best in areas where the source aquifer is of high quality and the well's contamination comes from a fixable, temporary problem, such as a faulty seal (Eykelbosh, 2013). Treatment of water at the well level does nothing to address the true cause of long-term potential contamination (such as latrines too close to the well or surface animal excreta leaching through sandy soil). If the aquifer the well draws from is contaminated, the contaminated water will seep back in soon after shock chlorination is conducted. Bleaching the well also does not address the potential for windblown contaminants or fallen materials to enter uncovered wells soon after the bleaching is completed. Using bleach at the well level may offer villagers a false sense of security about the safety of their water. In Rowe (1998), villagers responded that bleaching their wells would protect the water for between two weeks and six months, whereas in reality it protects or a day or two at most.

For these reasons, bleach treatment at the well level cannot be recommended. It is more advantageous to chemically treat water at the point-of-use level. Therefore, I decided to focus the Barrier Analysis survey on Treaters who used bleach to treat their drinking water at the point-of-use level and Non-Treaters who did not. 


\section{SURVEY METHODS:}

The survey questions were developed based on protocols and suggestions in Bonnie Kittle's Guide to Barrier Analysis (2013). A BA survey covers several possible determinants for behavior change (Table 1) in relation to a specific behavior (in this case, treating drinking water at the point-of-use level with bleach). According to Kittle's Guide, typically 45 "doers" and 45 "non-doers" for a specific behavior are interviewed for a BA survey. The questions on a BA survey are open-ended, and the focus is on understanding what the respondents are really saying, rather than the development worker educating on the "correct" way to answer or to act. The results of a BA survey can be used to better target future interventions to better address the population at hand. BA surveys are usually utilized during the planning phase of project development, to help structure future programming for optimal efficacy.

Barrier Analysis (BA) is recommended for Peace Corps work because it delves into deeper, harder-to-see explanations for behaviors. Lasting behavior change can succeed or be thwarted for a wide variety of complex reasons, many of which can be unknown even to the person performing the behavior. One needs only to examine their own health behaviors to see that this is the case. Many people may choose to occasionally disregard the FDA guidelines for exercise, sugar limitation, tooth flossing, etc., even though it is widely known and accepted which behaviors are "correct." Since the true reasons for behaviors can be unknown even to the individuals performing the behavior, they can be even more difficult to discern for development workers operating in an unfamiliar culture.

A BA survey was appropriate for the Kolda population because water treatment using bleach was not a novel concept in the region. During my time serving as a Peace Corps Volunteer in Senegal, I saw that bleach was commonly available and that most people I asked about the practice had heard of bleaching their londes before. In fact, when the survey results were tabulated, I found that $87.8 \%$ of survey respondents had added bleach to their londes at some point. On survey question 1, asking whether respondents thought they would be able to bleach their water (Table 1), 91 of the 97 people surveyed ( $94 \%$ of respondents) said they could. Despite prevalent knowledge of the practice, very few West Africans actually treat their drinking water (estimated to be $5 \%$ of the population or less - Rosa 2010 and McMahon 2013). The low number of Senegalese water Treaters is not caused by a lack of knowledge about the practice - the overwhelming majority had heard about water treatment, tried it, and for some reason decided not to stick with it. A BA survey was a useful tool to discern some possible reasons for this discrepancy.

The completed BA survey used consisted of 16 questions based around 12 behavioral determinants, with half of the questions being multiple choice and the others being written response (Table 1). Samba Kande, a Pulaar language coach who works for 
Peace Corps, generously volunteered his time to critique and edit the Pulaar translations on the survey for understandability.

A total of 97 surveys (46 water Treaters and 51 Non-Treaters) were conducted from January-March of 2016 by 11 Peace Corps Volunteers serving in the region of Kolda (Table 2). All surveys were conducted in Fulakunda Pulaar, the dominant local language of Kolda, either in the volunteers' own sites or in surrounding communities. The surveys took around 15 minutes each to conduct, although interview time was variable based on the talkativeness or reticence of the respondent. Language barrier concerns were minimal because all Peace Corps Volunteers in Senegal receive over 145 hours of language instruction as part of their pre-service training and all must test at the "Intermediate-Mid" local language level before swearing in as Peace Corps Volunteers. The survey questions were written in both Pulaar and in English, and volunteers were encouraged to write down any Pulaar responses they did not understand so Pulaar language coach Samba Kande could translate them later. All volunteers conducting surveys had been living and working in their communities, communicating exclusively in Pulaar, for at least seven months prior to the start of this project.

There were a total of 20 communities represented by the surveys (Figure 5 and Table 2). Surveyed communities were chosen by the 11 Peace Corps Volunteer surveyors.

Generally, volunteers chose to interview people that they knew well, as that produced a more frank and honest interview. Volunteers conducting the surveys were requested to find four Treaters and four Non-Treaters if possible. Due to the low prevalence of Treaters in the region, priority was placed on the survey team finding enough Treaters rather than on a truly random sampling of respondents. Most surveys were conducted in the Peace Corps Volunteers' home villages, though they occasionally branched out to other communities if they had trouble meeting their "Treater" quota in their own communities. Since the majority of the study population is illiterate (in Kolda, the literacy rate is $43.7 \%$ (ANSD)), the surveys were conducted orally.

Everyone surveyed for this study was in the Pulaar ethnic group (which is the overwhelming majority ethnic group in the region), relied on uncovered wells considered by the WHO to be "unprotected" as their water source, and had a child less than five living in their home at the time of the study. Respondents were told that they would not be allotted any gifts or compensation in exchange for participating in the study. Care was taken to survey respondents throughout the region of Kolda, though no major differences between different parts of the region are known. After all surveys were completed, the results were tabulated and grouped into categories, and calculations (including ChiSquare, Paired Student's T-Test, Unpaired T-Test, and Independent Samples T-Test) were run using SPSS. Graphs were created both in SPSS and in Microsoft Excel. No identifying information about the respondents was recorded, and the surveys were destroyed after all information had been tabulated. This project received IRB approval from Michigan Technological University Human Subjects Committee. 
Table 1: Barrier Analysis survey questions

\begin{tabular}{|c|c|c|}
\hline Determinant Addressed & Question Asked (English) & Response Type \\
\hline 1. Perceived Self-efficacy & $\begin{array}{l}\text { With your present knowledge, money, } \\
\text { and skills, do you think you could treat } \\
\text { your water with bleach? }\end{array}$ & $\begin{array}{l}\text { Multiple choice (yes, } \\
\text { possibly, no) }\end{array}$ \\
\hline 2. Perceived Self-efficacy & $\begin{array}{l}\text { What (makes/would make) it easier for } \\
\text { you to treat your water with bleach? }\end{array}$ & Open-ended \\
\hline 3. Perceived Self-efficacy & $\begin{array}{l}\text { What (makes/would make) it more } \\
\text { difficult for you to treat your water with } \\
\text { bleach? }\end{array}$ & Open-ended \\
\hline $\begin{array}{l}\text { 4. Perceived Positive } \\
\text { Consequences }\end{array}$ & $\begin{array}{l}\text { What are the advantages of treating } \\
\text { your water with bleach? }\end{array}$ & Open-ended \\
\hline $\begin{array}{l}\text { 5. Perceived Negative } \\
\text { Consequences }\end{array}$ & $\begin{array}{l}\text { What are the disadvantages of treating } \\
\text { your water with bleach? }\end{array}$ & Open-ended \\
\hline 6. Perceived Social Norms & $\begin{array}{l}\text { (Do/Would) most of the people you } \\
\text { know approve of you treating your water } \\
\text { with bleach? }\end{array}$ & $\begin{array}{l}\text { Multiple choice (yes, } \\
\text { possibly, no) }\end{array}$ \\
\hline 7. Perceived Social Norms & $\begin{array}{l}\text { Who are the people that (approve/would } \\
\text { approve) of you treating your water with } \\
\text { bleach? }\end{array}$ & Open-ended \\
\hline 8. Perceived Social Norms & $\begin{array}{l}\text { Who are the people that } \\
\text { (disapprove/would disapprove) of you } \\
\text { treating your water with bleach? }\end{array}$ & Open-ended \\
\hline 9. Perceived Access & $\begin{array}{l}\text { How difficult is it to get the materials you } \\
\text { need to treat your water with bleach? }\end{array}$ & $\begin{array}{l}\text { Multiple choice (very } \\
\text { difficult, somewhat } \\
\text { difficult, not difficult at } \\
\text { all) }\end{array}$ \\
\hline $\begin{array}{l}\text { 10. Perceived Cues for } \\
\text { Action }\end{array}$ & $\begin{array}{l}\text { How difficult is it to remember to treat } \\
\text { your water with bleach? }\end{array}$ & $\begin{array}{l}\text { Multiple choice (very } \\
\text { difficult, somewhat } \\
\text { difficult, not difficult at } \\
\text { all) }\end{array}$ \\
\hline 11. Perceived Susceptibility & $\begin{array}{l}\text { How likely is it that you, your child, or } \\
\text { someone in your family will get sick } \\
\text { from diarrhea in the next three months? }\end{array}$ & $\begin{array}{l}\text { Multiple choice (very } \\
\text { likely, somewhat likely, } \\
\text { not likely at all) }\end{array}$ \\
\hline 12. Perceived Severity & $\begin{array}{l}\text { How serious would it be if you or the } \\
\text { children got diarrhea? }\end{array}$ & $\begin{array}{l}\text { Multiple choice (very } \\
\text { serious, somewhat } \\
\text { serious, not serious at } \\
\text { all) }\end{array}$ \\
\hline 13. Perceived Divine Will ${ }^{*}$ & In your opinion, what causes diarrhea? & Open-ended \\
\hline 14. Action Efficacy & $\begin{array}{l}\text { How likely is it that you or your children } \\
\text { would get diarrhea if they were to drink } \\
\text { untreated water? }\end{array}$ & $\begin{array}{l}\text { Multiple choice (very } \\
\text { likely, somewhat likely, } \\
\text { not likely at all) }\end{array}$ \\
\hline 15. Culture & $\begin{array}{l}\text { Are there any cultural rules or taboos } \\
\text { against treating your drinking water with } \\
\text { bleach? }\end{array}$ & $\begin{array}{l}\text { Multiple choice (yes, } \\
\text { maybe, no) }\end{array}$ \\
\hline 16. Universal motivators & $\begin{array}{l}\text { What is the one thing you desire most in } \\
\text { life? }\end{array}$ & Open-ended \\
\hline
\end{tabular}

*Note: in Kittle's Guide to Barrier Analysis (2013), Perceived Divine Will is addressed as a multiple choice question (ie, do you think God causes diarrhea), but it was restructured to be open-ended for this survey. No respondent mentioned God as a cause of diarrhea (see Figure 22). Other work on perceived diarrheal causes (McMahon 2013) shows that in Sierra Leone, God is also not considered to cause diarrhea. 


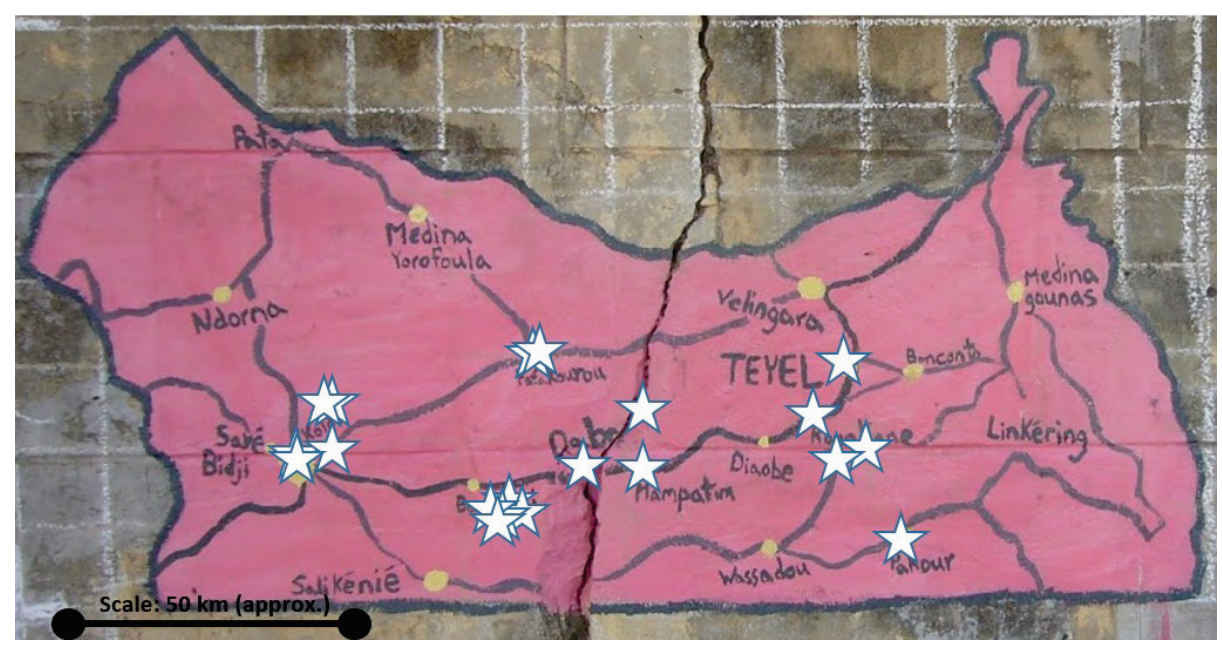

Figure 8. Locations of the surveyed communities in the Senegalese region of Kolda. Mural and photo credit: Barbara Michel

Table 2: Sites used for surveys

\begin{tabular}{|c|c|c|c|c|}
\hline $\begin{array}{l}\text { Type of } \\
\text { Community }\end{array}$ & $\begin{array}{l}\text { Population } \\
\text { Range }\end{array}$ & $\begin{array}{l}\text { Communities } \\
\text { sampled }\end{array}$ & $\begin{array}{l}\text { Treater } \\
\text { surveys }\end{array}$ & $\begin{array}{l}\text { Non-Treater } \\
\text { surveys }\end{array}$ \\
\hline Small Village & $0-500$ & $\begin{array}{l}\text { Fass Kahone } \\
\text { Kayal } \\
\text { Mamadou Aliou } \\
\text { Sare Bocary } \\
\text { Sare Gueladio } \\
\text { Sare Hamidou } \\
\text { Sare Keita } \\
\text { Sare Mama Tening } \\
\text { Sare Meta } \\
\text { Sare Moussa } \\
\text { Sare Nianthio } \\
\text { Sare Sambou Diabba } \\
\text { Thiarp }\end{array}$ & $\begin{array}{l}1 \\
0 \\
4 \\
1 \\
3 \\
0 \\
1 \\
0 \\
2 \\
1 \\
0 \\
2 \\
1\end{array}$ & $\begin{array}{l}3 \\
1 \\
4 \\
0 \\
4 \\
4 \\
0 \\
2 \\
0 \\
0 \\
1 \\
6 \\
2\end{array}$ \\
\hline Medium Village & $501-1200$ & $\begin{array}{l}\text { Diankankounda Ogel } \\
\text { Teyel }\end{array}$ & $\begin{array}{l}4 \\
4\end{array}$ & $\begin{array}{l}4 \\
4\end{array}$ \\
\hline Large Village & $1201-5000$ & $\begin{array}{l}\text { Mampatim } \\
\text { Pakour }\end{array}$ & $\begin{array}{l}2 \\
4\end{array}$ & $\begin{array}{l}5 \\
4\end{array}$ \\
\hline City & $5001-10,000$ & $\begin{array}{l}\text { Dabo } \\
\text { Kounkane }\end{array}$ & $\begin{array}{l}6 \\
4\end{array}$ & $\begin{array}{l}2 \\
4\end{array}$ \\
\hline \multirow[t]{2}{*}{ Regional Capital } & $10,001+$ & Kolda & 5 & 2 \\
\hline & & Total: 97 & 46 & 51 \\
\hline
\end{tabular}


Microbial testing to determine the efficacy of point-of-use water treatment at the household level was done using $3 \mathrm{M}$ Petriflms ${ }^{\mathrm{TM}}$ due to their ease of use in the field. Because the supply of Petriflms ${ }^{\mathrm{TM}}$ was limited, only four of the twenty communities surveyed were chosen for water sampling. The sampling sites (Table 3) were chosen as a representative of the demographics

of Kolda as a whole - roughly $75 \%$ village and $25 \%$ urban. Residents of all communities sampled depend on wells classified as "unimproved" by Peace Corps and WHO for their drinking water needs. All wells sampled are a water source yearround, as they retain productivity through dry season.

Testing was conducted during February and March of 2016. Most tests were done in triplicate. When a sample's fidelity was questionable due to faulty technique, additional sample(s) were prepared, but there were never fewer than three samples taken.

Sterile disposable pipettes were used to transfer the water samples to the testing media (Figure 9).

Each new pipette was flushed with the sample twice before collection

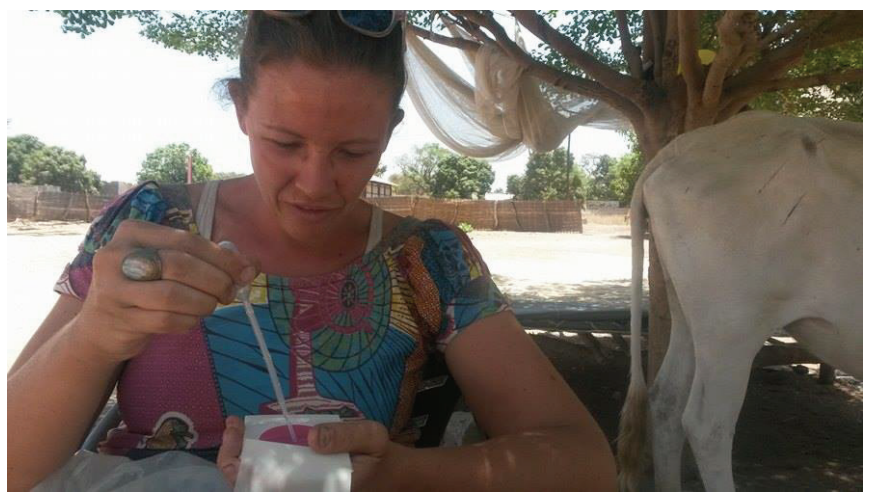

Figure 9. Peace Corps Volunteer Barbara Michel (author) pipettes water in Dabo, Kolda, Senegal, as a cow stands nearby. Photo credit: Alicia Gorina

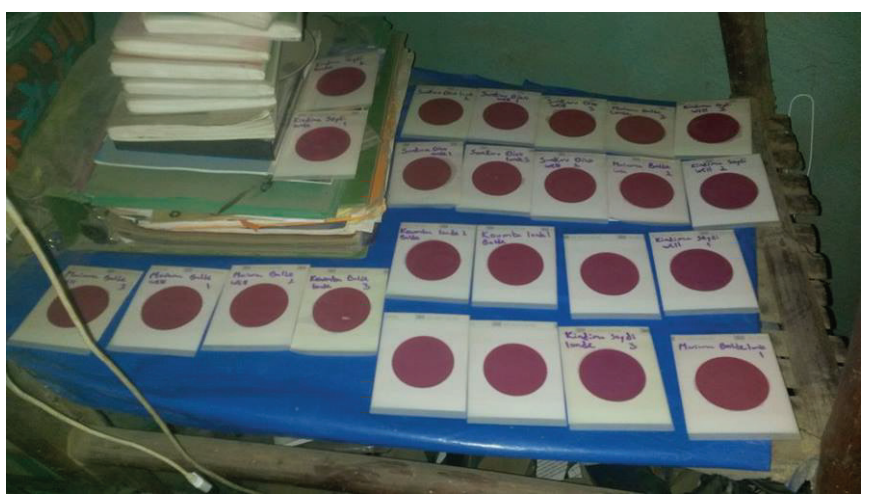

Figure 10. Petrifilms ${ }^{\mathrm{TM}}$ incubate in the room of Peace Corps Volunteer Alicia Gorina in Dabo. Photo credit: Alicia Gorina

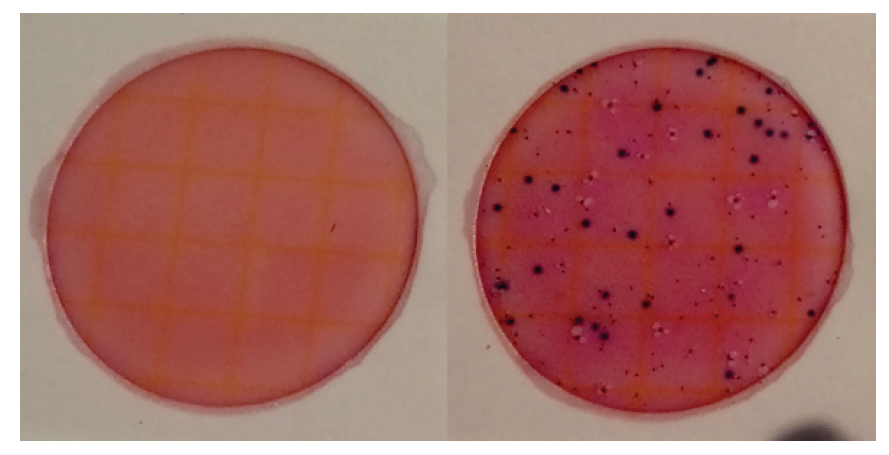

Figure 11. Two petrifilms, one showing no microbial growth (left) and one showing significant E. coli (blue) and coliform (red) colonies. Photo credit: Barbara Michel began and was disposed of after use. Well samples were taken directly from the well bucket, and londe samples were taken from the plastic cup used with the londe (Figure 7). The londe water was obtained by the member of the household who normally fetches water (usually a child) so the most authentic sample possible was obtained. After a $1 \mathrm{~mL}$ sample was placed on the Petrifilm ${ }^{\mathrm{TM}}$ media, the Petrifilm ${ }^{\mathrm{TM}}$ was incubated at ambient 
volunteer for 24 hours (Figure 10), and coliform/E. coli counts were recorded the next day.

Due to the limitations of doing fieldwork in a resource-poor environment, the counts reported should be considered approximations. The Petrifilms ${ }^{\mathrm{TM}}$ were not incubated at ideal laboratory temperatures, and in several cases some water spilled out the sides of the films during collection. Ideally, the films would have been kept refrigerated until they were used, but due to conditions in Senegal they were kept unrefrigerated for a month prior to use.

In spite of these limitations, the Petrifilms ${ }^{\mathrm{TM}}$ still performed well and there were no indications to suggest the results were unreliable. Since the WHO threshold for clean water is 0 coliforms or $E$ coli in $100 \mathrm{~mL}$ of water and only $1 \mathrm{~mL}$ of water was sampled per Petrifilm ${ }^{\mathrm{TM}}$ for this research, it cannot be definitively said that films with no colony growth had truly "clean" water - however, it can be said that those films that showed growth did show true contamination. The Petriflms ${ }^{\mathrm{TM}}$ also served as a useful visual aid to demonstrate the importance of water treatment to the largely illiterate population, since the colonies were obvious and striking (Figure 11). After the data from the Petriflms ${ }^{\mathrm{TM}}$ was recorded and photos were taken, the films were given to the communities' health care workers to use in future educational programming.

Table 3: Sites chosen for water sampling in Kolda.

\begin{tabular}{|c|c|c|c|}
\hline $\begin{array}{l}\text { Community } \\
\text { name }\end{array}$ & $\begin{array}{l}\text { Community } \\
\text { type }\end{array}$ & Well information & $\begin{array}{l}\text { Water Sources } \\
\text { Sampled }\end{array}$ \\
\hline Sare Meta & $\begin{array}{l}\text { Small village } \\
\text { (population } \\
150 \text { ) }\end{array}$ & $\begin{array}{l}\text {-Only well is } 23 \text { meters deep and fully cement lined. } \\
\text {-Well is usually bleached }(1 \mathrm{~L}) \text { in the rainy season }\end{array}$ & $\begin{array}{l}-1 \text { well (used by al } \\
\text { respondents) } \\
\cdot 2 \text { Treater londes } \\
\cdot 3 \text { Non-Treater } \\
\text { londes }\end{array}$ \\
\hline $\begin{array}{l}\text { Sare } \\
\text { Gueladio }\end{array}$ & $\begin{array}{l}\text { Small village } \\
\text { (population } \\
400 \text { ) }\end{array}$ & $\begin{array}{l}\text {-Two wells in the village are used by everyone. } \\
\text { "Cartier" well (Well A) is cement lined, } 20 \mathrm{~m} \text {, and } \\
\text { was bleached }(500 \mathrm{~mL}) \text { two weeks before sampling } \\
\text { - "Fodde" well (Well B) is unlined, } 15-17 \mathrm{~m} \text {, and was } \\
\text { bleached }(500 \mathrm{~mL}) \text { two months before sampling }\end{array}$ & $\begin{array}{l}-2 \text { wells (used by } \\
\text { all respondents) } \\
\cdot 2 \text { Treater londes } \\
\cdot 4 \text { Non-Treater } \\
\text { londes }\end{array}$ \\
\hline Teyel & $\begin{array}{l}\text { Medium village } \\
\text { (population } \\
1000 \text { ) }\end{array}$ & $\begin{array}{l}\text {-There are } 40 \text { wells in the village } \\
\text {-Most wells are hand-dug and }>10 \mathrm{~m} \\
\text {-One sampled well was cement-lined }\end{array}$ & $\begin{array}{l}\cdot 1 \text { Treater well } \\
\cdot 1 \text { Treater londe } \\
\cdot 3 \text { Non-Treater } \\
\text { wells } \\
\cdot 3 \text { Non-Treater } \\
\text { londes }\end{array}$ \\
\hline Dabo & $\begin{array}{l}\text { City } \\
\text { (population } \\
8000)\end{array}$ & $\begin{array}{l}\text {-There are } 300 \text { wells in the city } \\
\text {-Most wells are hand-dug and }>10 \mathrm{~m} \cdot \text { One sampled } \\
\text { well is cement-lined } \\
\text {-One well had been bleached }(500 \mathrm{~mL} \text { bottle) two } \\
\text { days before sampling }\end{array}$ & $\begin{array}{l}-2 \text { Treater wells } \\
\cdot 2 \text { Treater londes } \\
\text {-2 Non-Treater } \\
\text { wells } \\
\text {-2 Non-Treater } \\
\text { londes }\end{array}$ \\
\hline
\end{tabular}




\section{RESULTS - SURVEYS}

In total, 97 surveys were conducted, reaching 46 "Treaters" who regularly treat their water with bleach as per the WHO recommendation and 51 "Non-Treaters" who utilize water directly from the well (Figure 12). It is estimated that $5 \%$ or less of the population regularly treats their water, so the surveys were not a representative sample of the population as a whole. The samples were predominantly done in villages (Figure 13 and Table 2). All respondents relied on wells classified as "unprotected" by the WHO for their water needs, all were part of the Pulaar ethnic group, and all had a child five or under living in the household at the time of surveying.

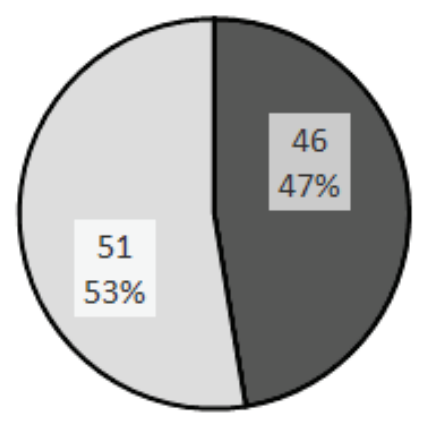

Treater

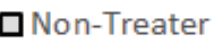

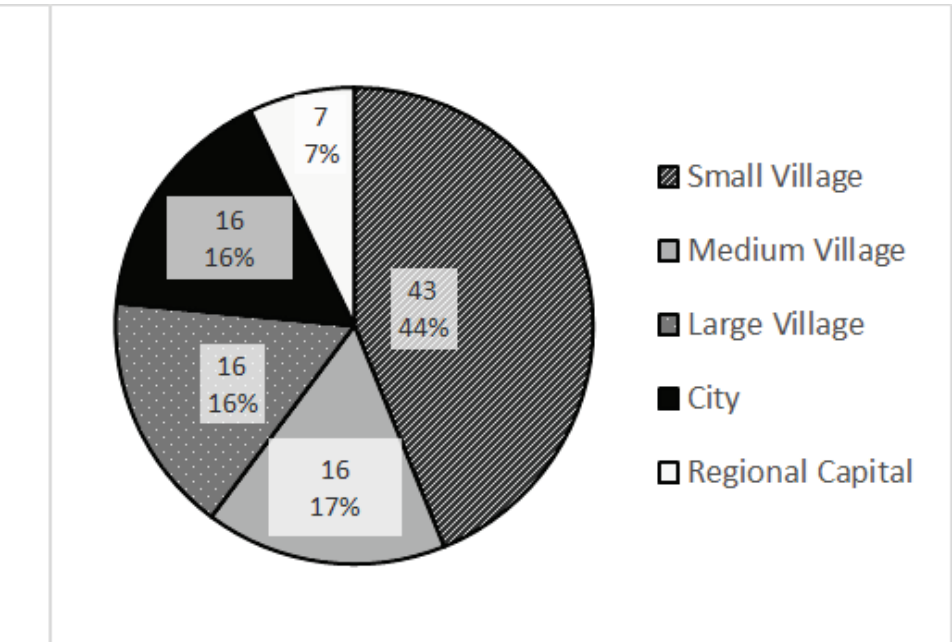

Figures 12 and 13: Classifications of individuals reached by the surveys

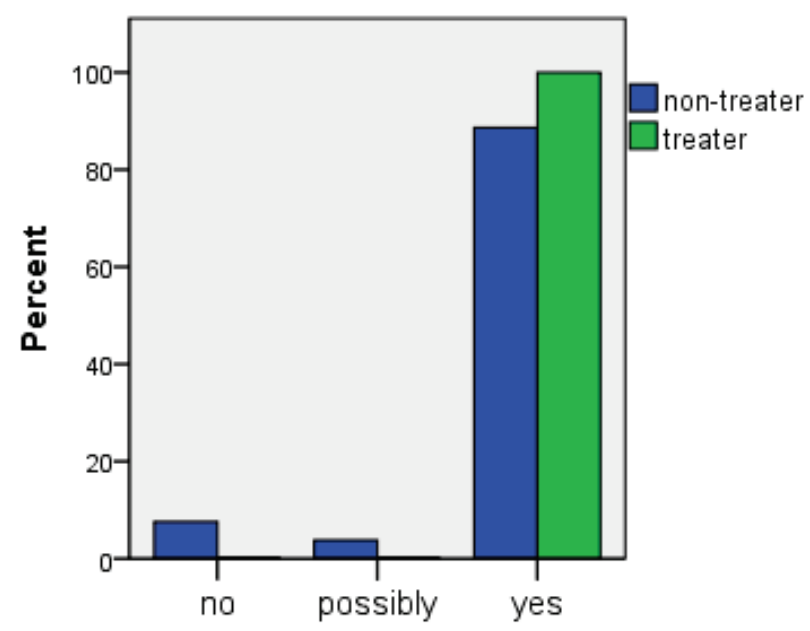

Figure 14: Responses for survey question \#1 (With your present knowledge, money, and skills, do you think that you could chemically treat your water.) Most of the Non-Treaters (88\%) and all of the Treaters said that they could. 
Although $94 \%$ of all survey respondents said they would be able to treat their water (Figure 14), the variation in the amount of bleach the Treaters reported using indicates that there was some confusion of the correct dose (Figure 15). A cap of the local bleach available at the study site (MADAR ${ }^{\mathrm{TM}}$ ) was observed to hold approximately $6 \mathrm{~mL}$ of liquid during field testing, but since it was normal boutique bleach not marketed for water treatment, the cap was not designed to be utilized as a measurement device. It was assumed that all "capfuls" referred to the caps of MADAR ${ }^{\text {TM }}$, but it's possible they referred to the cap of another bottle. Most surveyed Treaters (51\%) reported that they used more bleach than the $\mathrm{WHO}$ recommendation to treat their water.

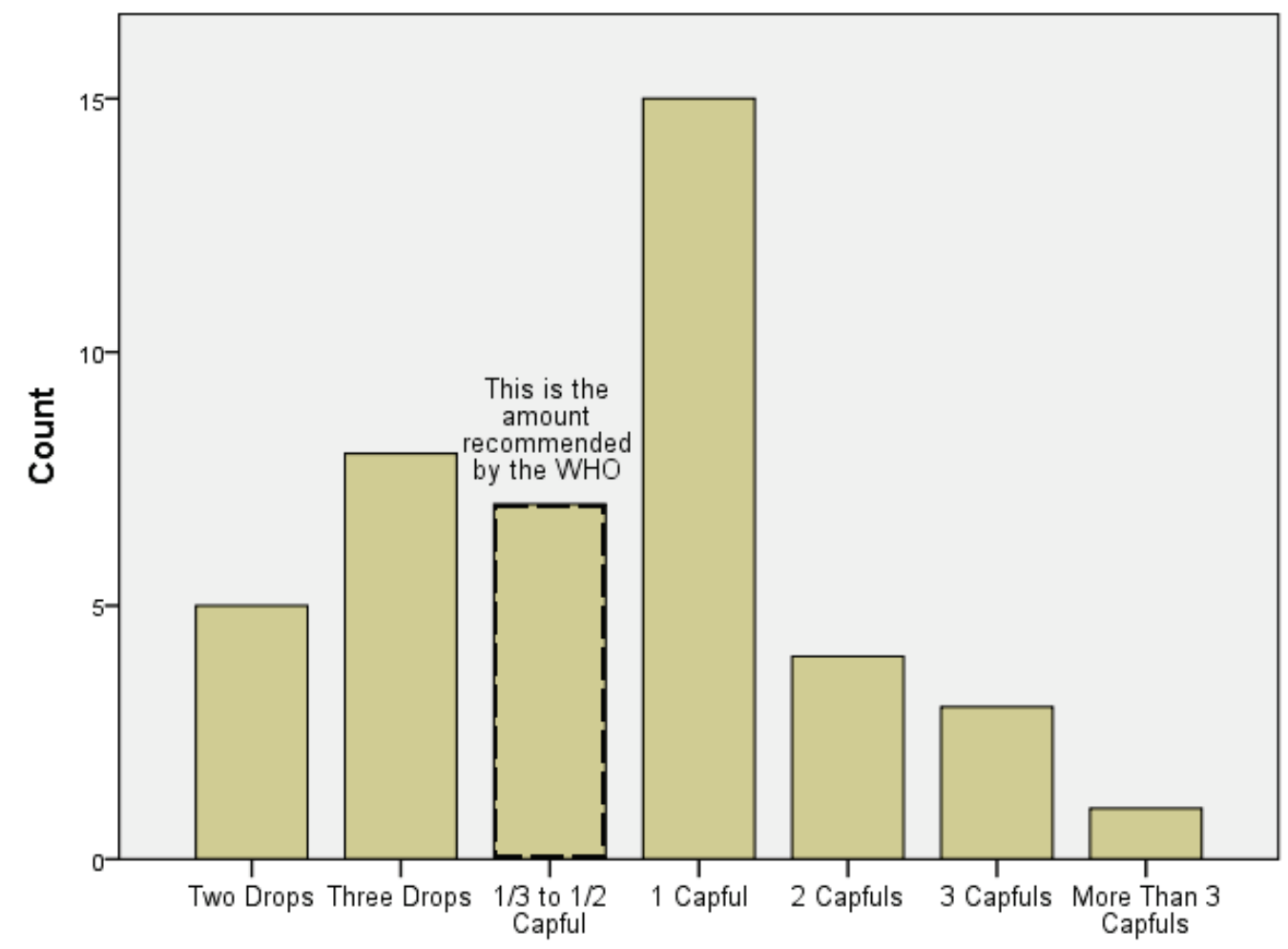

Figure 15: Histogram of the amount of bleach that the surveyed water Treaters reported using. One capful of Madar ${ }^{\mathrm{TM}}$ bleach is roughly equivalent to $6 \mathrm{~mL}$. The WHO recommended dosage is $2.11-4.22 \mathrm{~mL}$ per $20 \mathrm{~L}$ londe. See also Figure 31 for boxplots comparing reported bleach use in surveys and observed bleach use from water sampling.

Surprisingly, the Non-Treaters also reported a high frequency of bleach use. Only 9 of the 51 Non-Treaters (18\%) said that they "never" used bleach as a water treatment method. Most people surveyed, even if they do not currently bleach their water, reported that they have done so in the past. The seven Non-Treaters who responded that they treat their water "daily" are classified as Non-Treaters for the purposes of this research because at the time of surveying, they admitted that they had not actually added any bleach to their londes that day, either because they'd forgotten or they "just ran out of" bleach. 


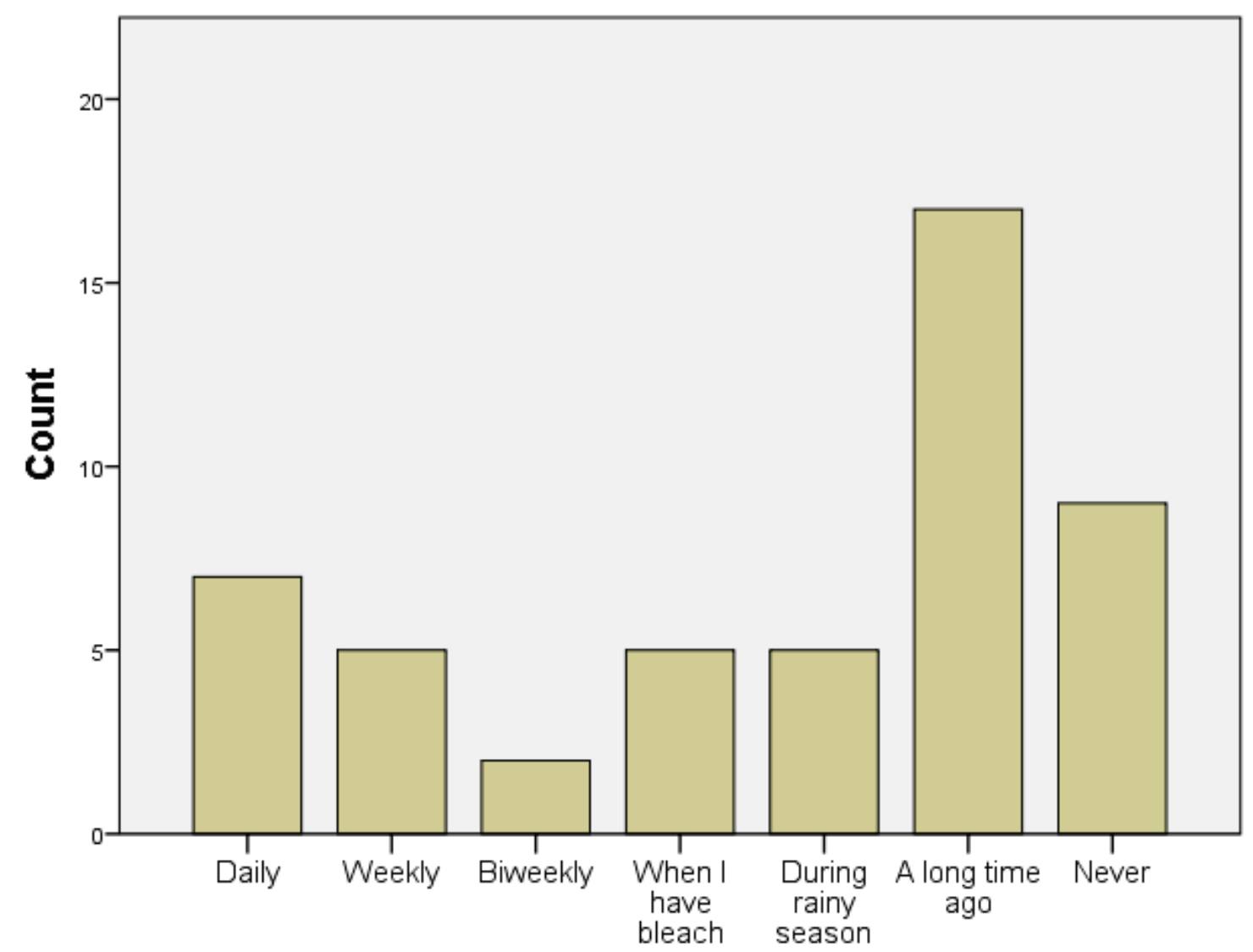

Figure 16: Survey responses of Non-Treaters when asked when they use bleach for the treatment of drinking water.

The majority of both Treaters and Non-Treaters cited no disadvantages to chlorine bleach treatment (Figure 17). However, a number of both Treaters and Non-Treaters reported that the use of bleach can be bad for the body or can taste bad. The majority of respondents who said treated water tasted bad (five out of the six) reported using the WHO-recommended dosage of $1 / 3-1 / 2$ capfuls per londe, and the remaining individual reported putting in two capfuls. Of the 10 respondents who responded that treated water was "bad for the body", 8 put in the WHO-recommended dosage or less.

Since the majority of Treaters and Non-Treaters cited no disadvantages to treating their water, I next looked at how easy they perceived the water treatment process to be. More Treaters than Non-Treaters responded that "Nothing" could make it easier for them to treat their water (39\% of Treaters compared to $6 \%$ of Non-Treaters - see Figure 18). Treaters were also more likely to say that establishing water treatment as a habit would make it easier for them to treat their water (11\% of Treaters compared to $2 \%$ of NonTreaters - see Figure 18). 


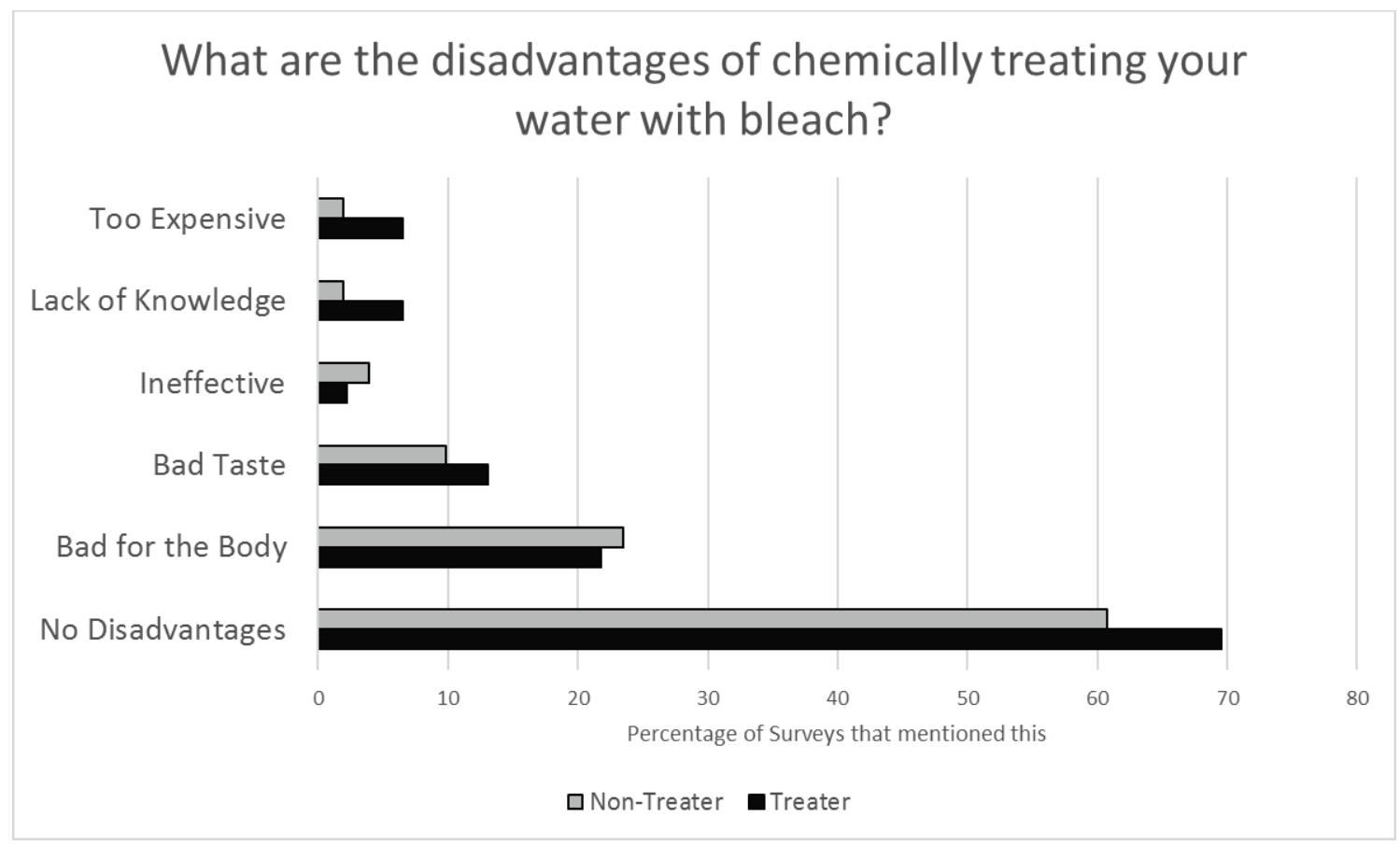

Figure 17: Results for survey question \#4

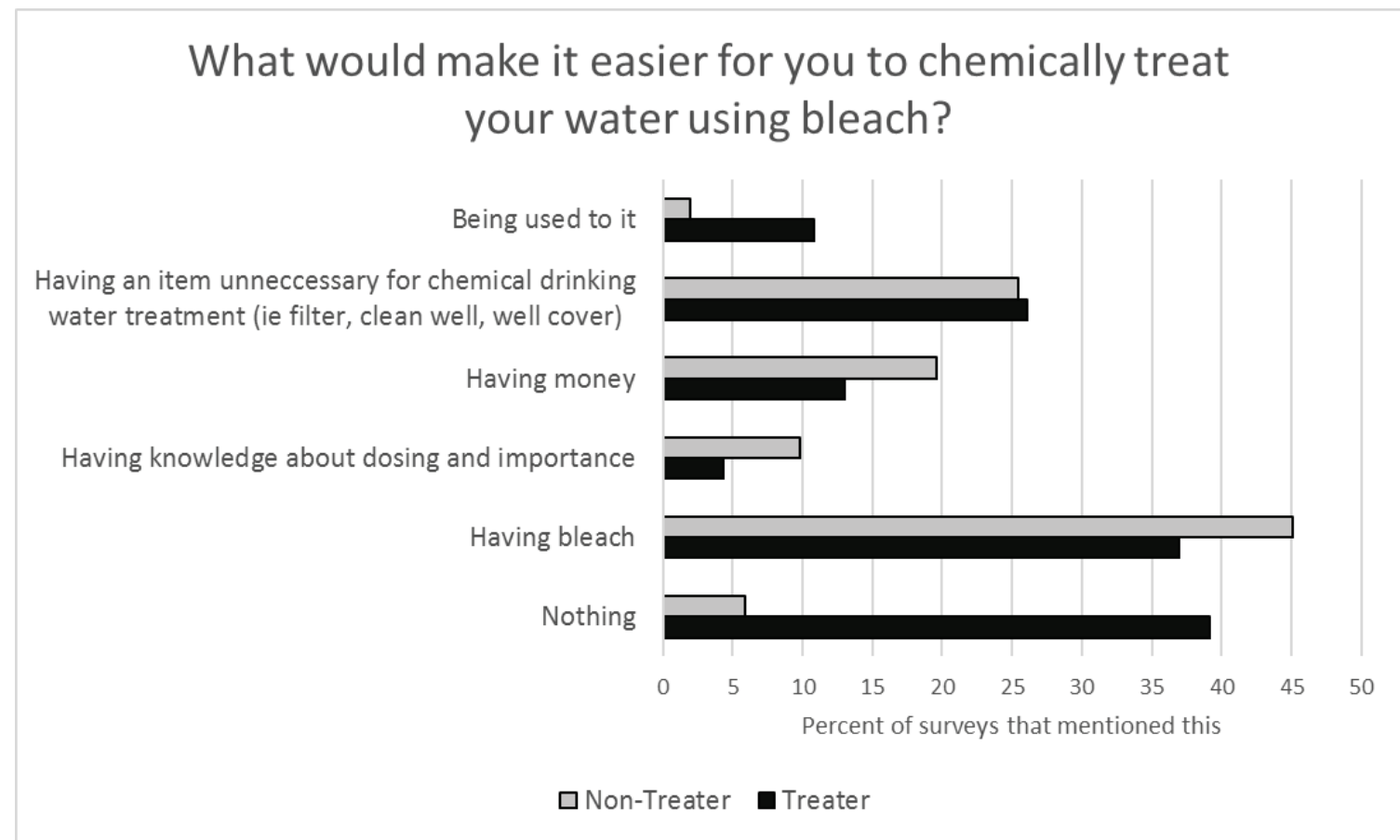

Figure 18: Results for the survey question \#2 
When asked what would make water treatment easier, the most popular response for Non-Treaters was "having bleach" (Figure 18). Since an overwhelming majority of all respondents said they could treat their water with their present knowledge, money, and skills (Figure 14), it was assumed that "having bleach" referred to accessibility of the bleach itself, rather than accessibility of money with which to buy bleach. Since people in smaller villages might be expected to have more difficulty accessing products for bleach treatment, the significance in the relationship between perceived availability of bleach and community size was investigated next.

Respondents in small villages were not significantly more likely to cite an access barrier than those in cities. No surveyed city dweller responded that it was "very difficult" to obtain bleach, but even in small villages, there were some respondents who said getting bleach was not difficult at all (Figure 19). When the perceived access barrier was examined across all individual communities, it was found that in three communities (Sare Sambou Diabba, Mamadou Aliou, and Diankankounda Ogel - see Table 2) the majority of respondents said it was "very difficult" to get materials. However, in each of those communities, there was at least one respondent who said it was "not difficult at all."

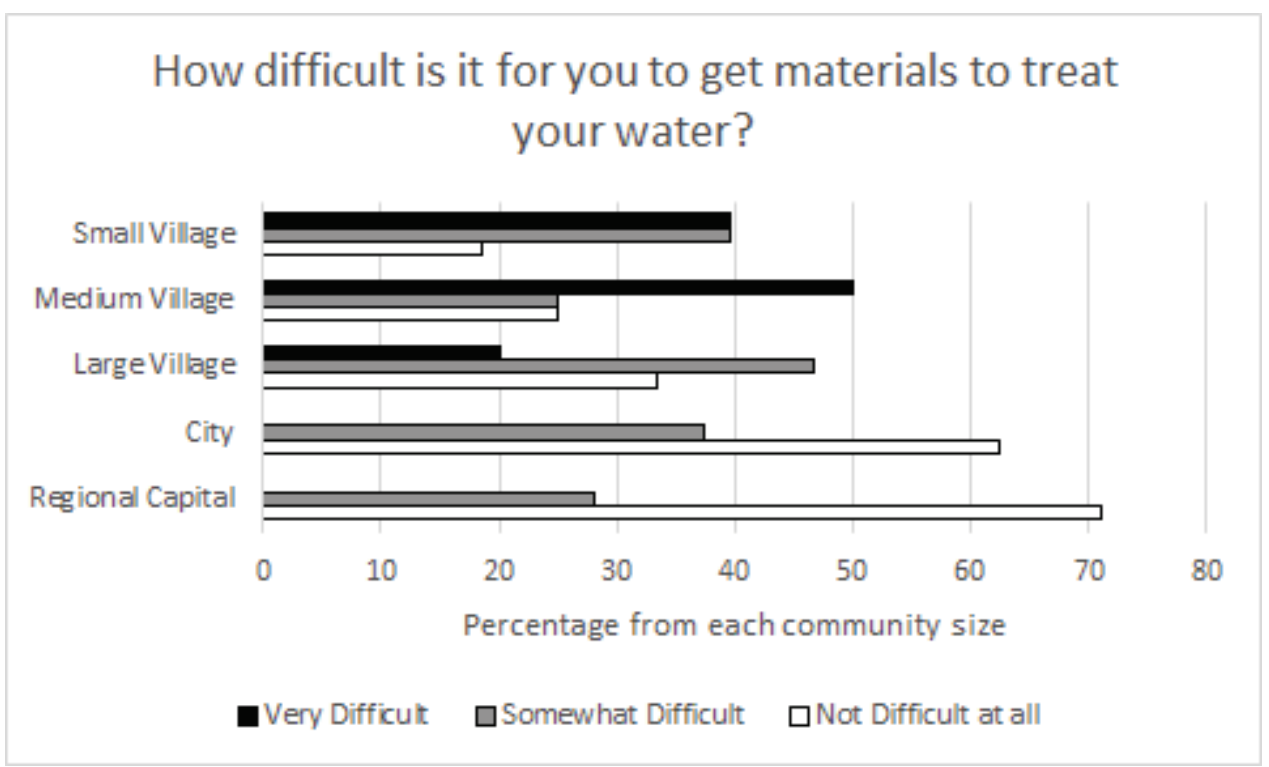

Figure 19: Results for survey question \#9. Survey respondents in cities (population 8000 or more) did not respond that it was "very difficult" to get the materials they need to chemically treat their water; however, differences were not significant. Pearson Chi-Square value 18.656, significance 0.097.

When asked who disapproved of treating water with bleach, the most popular answer for all respondents was that "no one" disapproved, but more Treaters than Non-Treaters answered this way (Figure $20-57 \%$ of Treaters compared to $37 \%$ of Non-Treaters). Men, old people, and guests were also mentioned as potential disapprovers. More Treaters than Non-Treaters said that kids disapprove of chemical water treatment $(9 \%$ of Treaters compared to $0 \%$ of Non-Treaters), but since the Treaters all treated their water regardless of their kids' expressed disapproval, children's agreement is not expected to be a strong barrier to water treatment behaviors. 


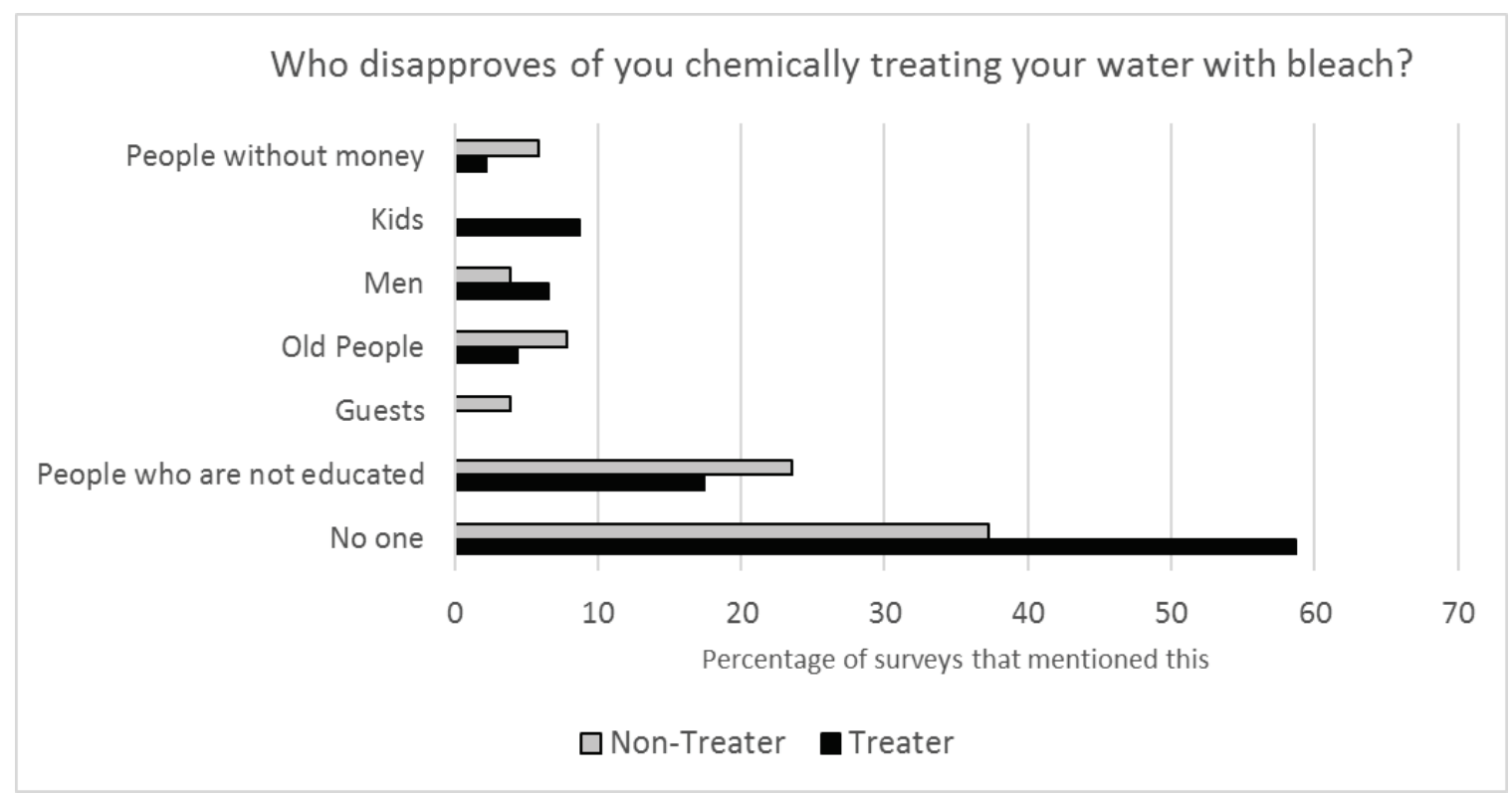

Figure 20. Results for survey question \#4.

Both Treaters and Non-Treaters listed several advantages of using bleach as a water treatment method (Figure 21). The most popular response was that treating water with bleach was good for health, with $79 \%$ of surveys listing it as an advantage. More Treaters than Non-Treaters said that health was an advantage (89\% of Treaters compared to $68 \%$ of Non-Treaters). Health was also found to be the most common universal motivator in the surveyed population for both Treaters and Non-Treaters (Figure 18).

Although Knowledge was a less popular universal motivator than Health, Money, or Peace, it is compelling that only Treaters listed Knowledge as something they desired most in life (Figure 22).

Since untreated water is known to cause diarrhea and preventing diarrhea is the main goal of water treatment interventions, the survey also examined perceptions of diarrheal disease causation. When asked what caused diarrhea, slightly less than half of surveys $(48 \%)$ cited "bad water" as a cause (Figure 26$)$. The most common response was food (either bad food, contaminated food, or wrong food) with $63 \%$ of surveys listing it $67 \%$ of Non-Treaters and $60 \%$ of Treaters). Note that only $7 \%$ of all survey respondents listed "illness" as a possible cause of diarrhea. Respondents were encouraged to list as many causes as they could think of. 


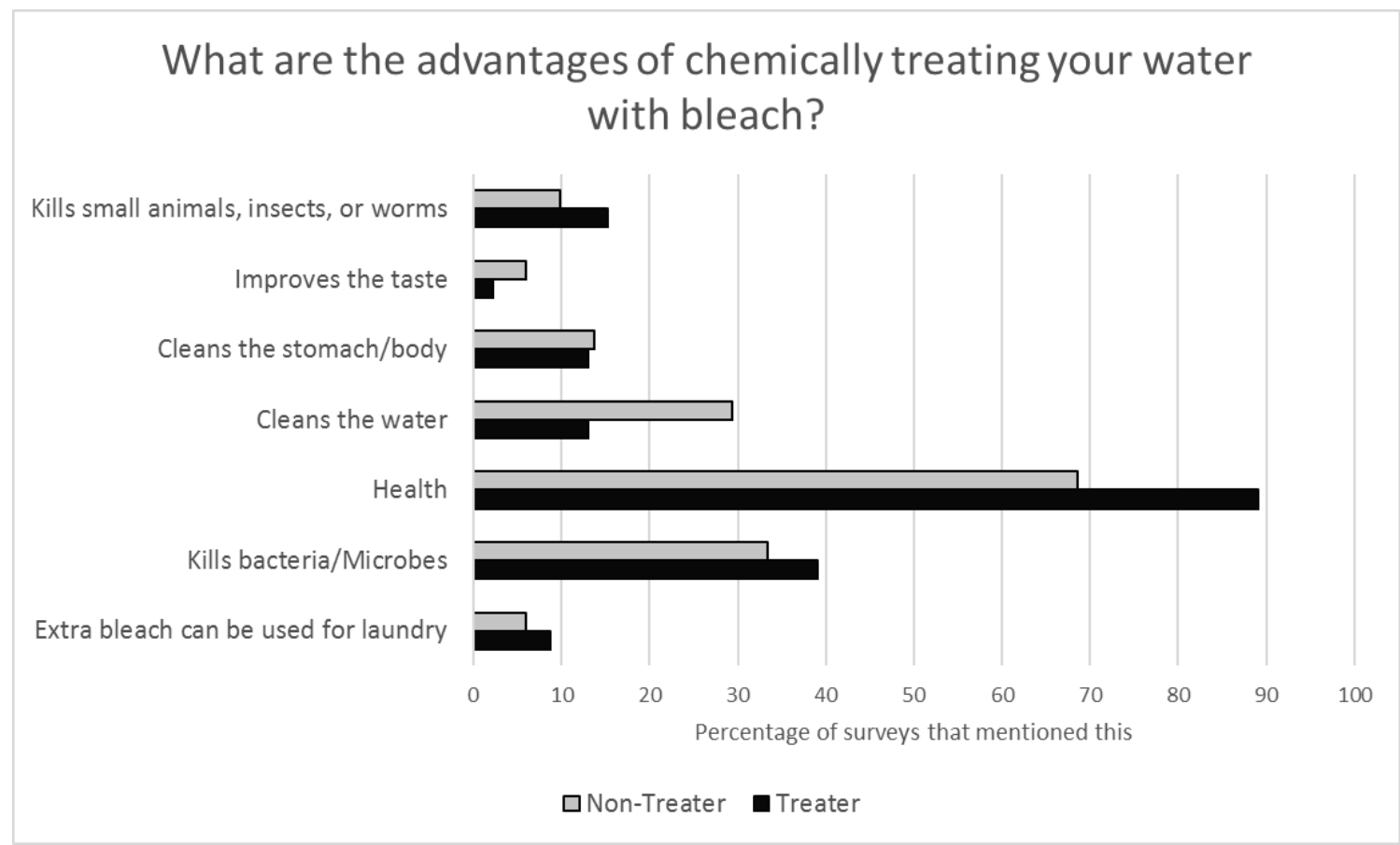

Figure 21. Results for survey question \#4

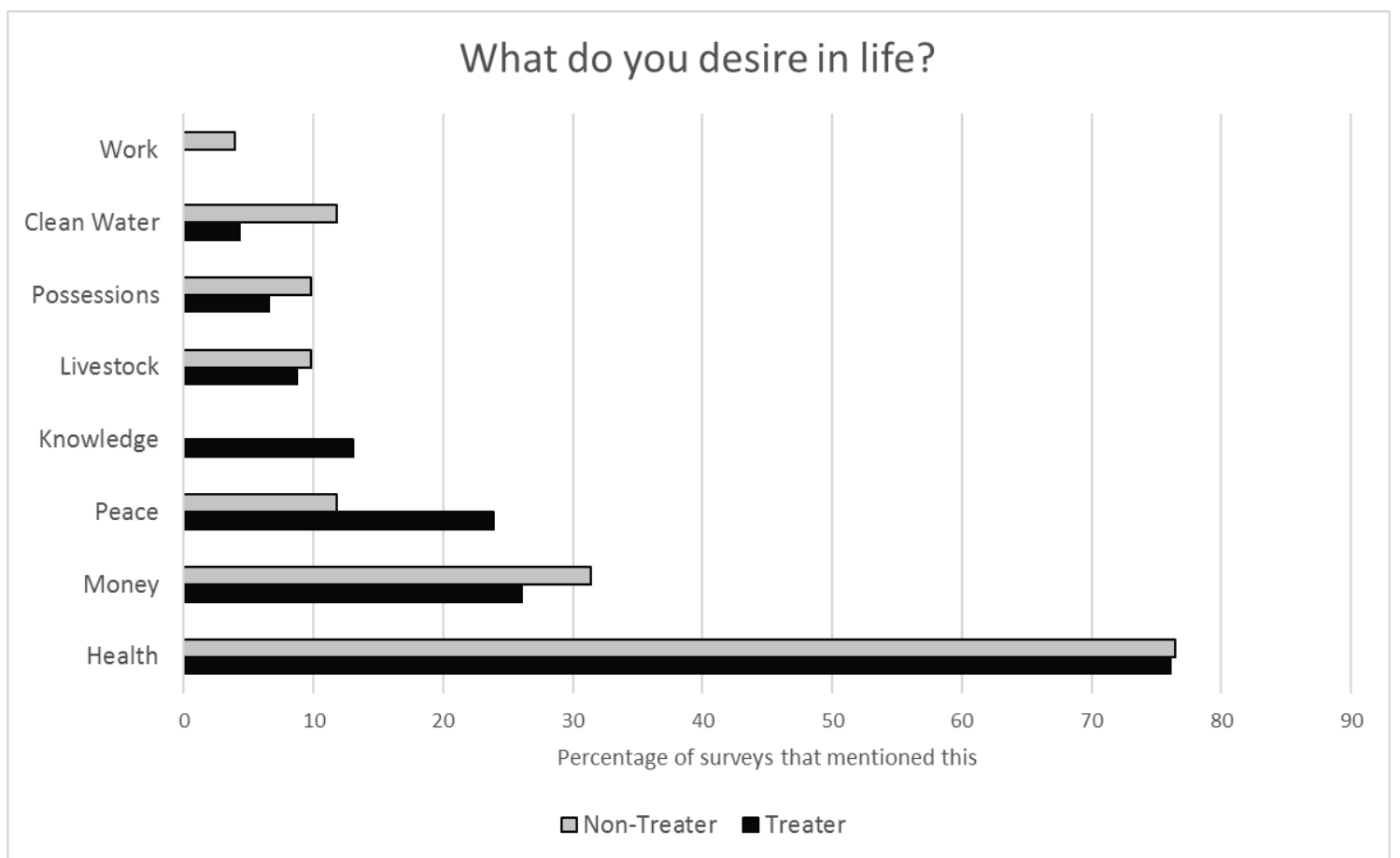

Figure 22. Results for the survey question \#16. Respondents gave from 1-4 responses, with 61 (63\%) giving one response, 27 (28\%) giving two responses, and $9(9 \%)$ giving three responses. One respondent gave four responses. The average number of responses was 1.49 . 
Nearly all respondents (91\%) said it was at least somewhat likely that untreated water would cause diarrhea (Figure 24). Interestingly, the Non-Treaters were more likely to say that they or their children were "not likely at all" to contract diarrhea through drinking untreated water ( $0 \%$ of Treaters compared to $14 \%$ of Non-Treaters). In contrast, amongst people that treated their water, drinking untreated water was always considered at least somewhat likely to produce diarrhea (Figure 24).

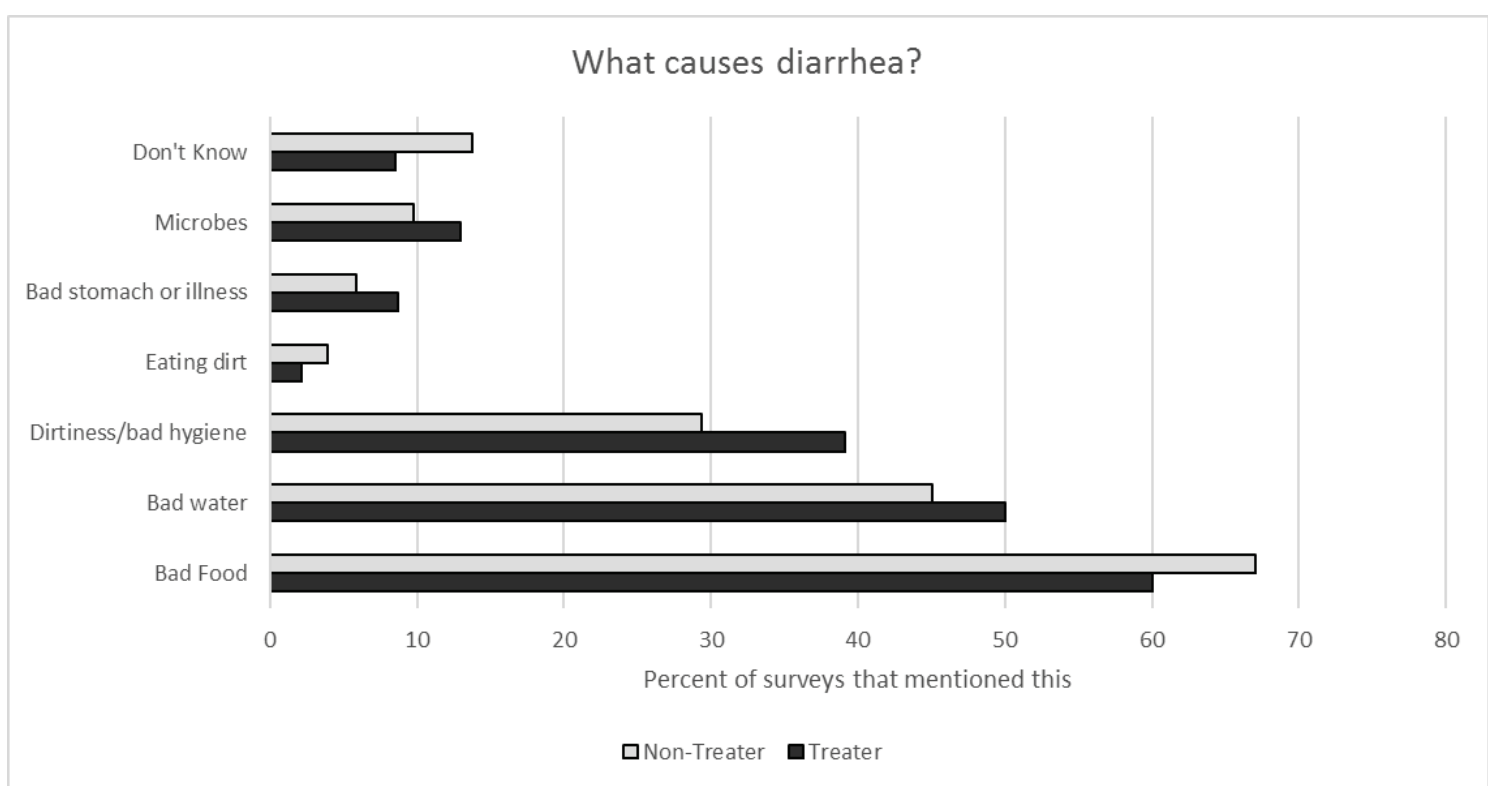

Figure 23: Results for the survey question \#13. Respondents gave from 1-5 responses, with 38 (39\%) giving one response, 37 (38\%) giving two, $17(18 \%)$ giving three, one (1\%) giving four, and $4(4 \%)$ giving five. The average number of responses was 1.92 .

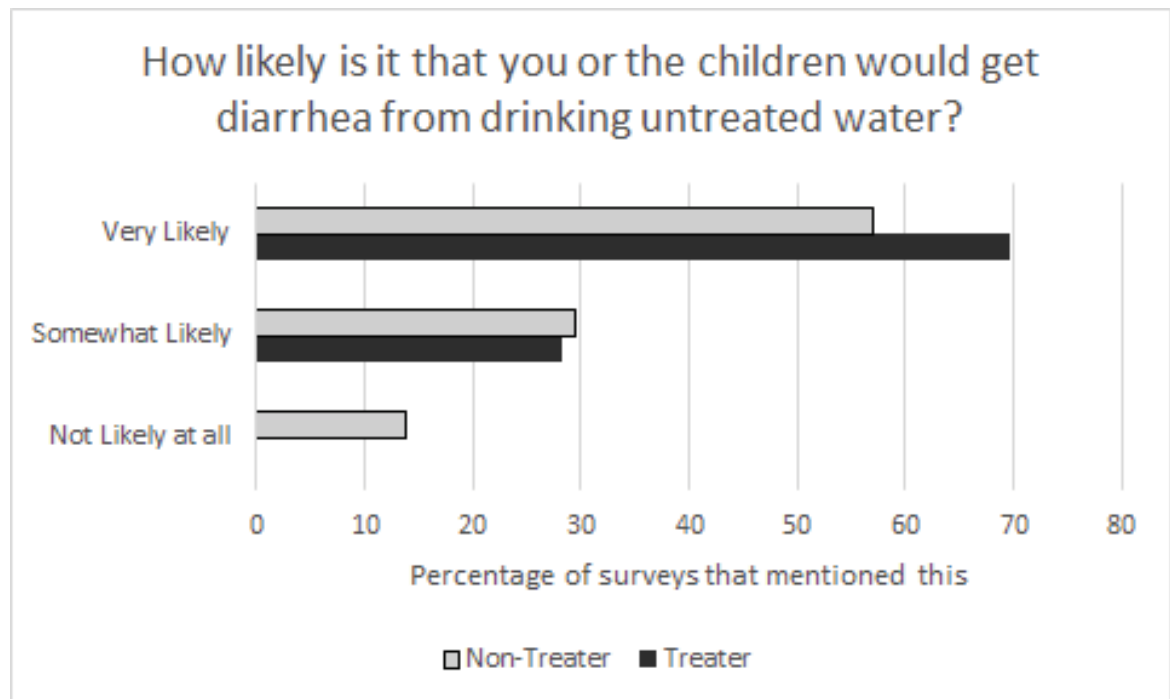

Figure 24. Results for survey question \#11. Note that only Non-Treaters responded it was "not likely at all" to get diarrhea from drinking untreated water. 


\section{RESULTS - PETRIFILMS TM}

\section{Cleanliness of Wells}

Contamination of wells with both coliforms and E. coli was common, though the degree of contamination varied widely (Figure 25). Since the WHO stipulates that water must have no coliforms or $E$ coli per $100 \mathrm{~mL}$ to be considered clean, all wells were found to be contaminated by this standard, since each well had coliform or E. coli growth on at least one replicate.

Of the 37 well water samples examined for this research, $34(91 \%)$ had at least one coliform colony and $19(51 \%)$ had at least one E. coli colony. Wells with high coliform contamination tended to have high $\mathrm{E}$. coli contamination as well. A paired student T-test between each well's coliform count and $E$. coli count showed a t-value of 2.21, $p=0.052$. Sare Gueladio Well B, the outlier with a very high E coli count in Figure 24, also had the second-highest concentration of coliforms of any sampled well.

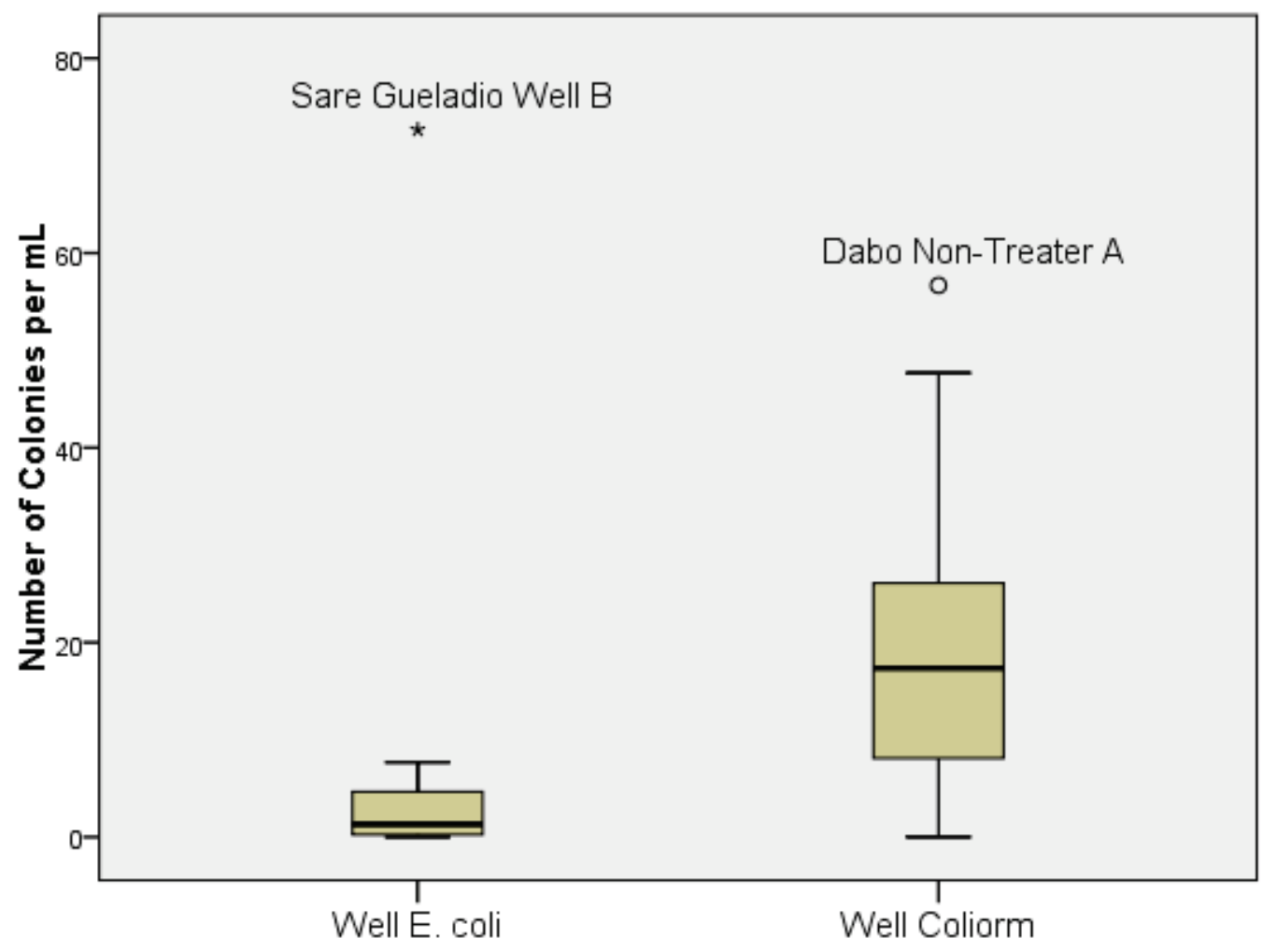

Figure 25: Boxplots showing the wide variation in E. coli and coliform contamination in wells, by average number of colonies on the Petrifilm ${ }^{\mathrm{TM}}$ testing media per $1 \mathrm{~mL}$ sampled water. Coliform: $\mathrm{N}=11$, mean $=20.85$, median =17.33. $\mathrm{E}$. coli: $\mathrm{N}=11$, mean $=8.65$, median $=1.33$.

Only one well (Dabo Non-Treater B) did not show any coliform contamination, perhaps because the well's owner said she had bleached it two days before sampling (Table 3). The same well did have a small amount of $E$ coli present in her well $(4,0$, and 1 colonies 
on the replicate plates, for an average of 1.33 colonies $/ \mathrm{mL}$ ). No well was completely free of contaminants. See appendix Tables 6 and 7 for average coliform and E. coli contamination for every well and londe studied.

\section{Contamination Differences Between Lined and Unlined Wells}

Of the eleven wells sampled, four were concrete-lined (15 Petrifilms ${ }^{\mathrm{TM}}$ ) and seven were unlined (22 Petrifilms ${ }^{\mathrm{TM}}$ ). The cement lined wells were significantly lower in coliforms than the unlined wells, but the difference was not significant for E coli (Figure 26). See Table 3 for more information about the wells in each community.

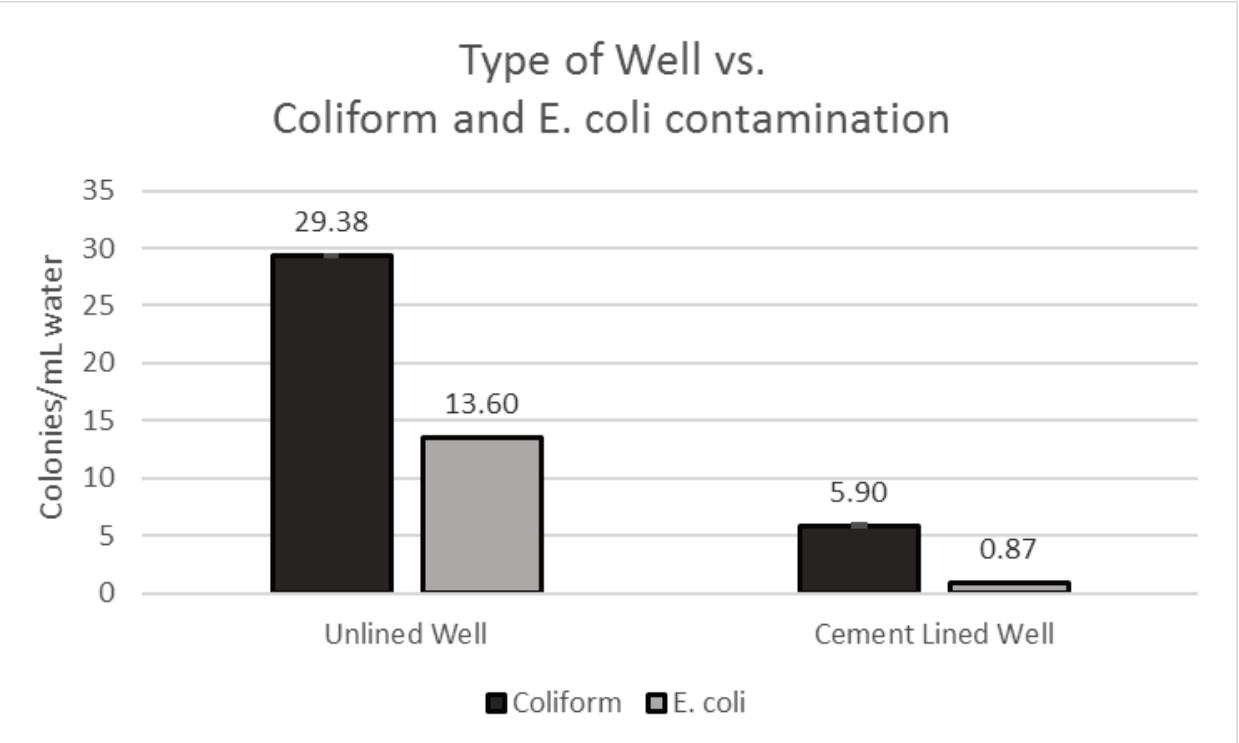

Figure 26: Comparison of coliform (dark bars) and E. coli (light bars) in unlined and lined wells. Unpaired ttest for difference in coliform counts: $t=5.536$, significance $<0.001$. Unpaired t-test for difference in $E$. coli counts between cement lined and unlined wells: $t=1.907$, significance $=0.065$. The average number of colonies $/ \mathrm{mL}$ for each column is shown.

\section{Contamination Differences Between Treated and Untreated Water}

The intervention of treating water with bleach at the point-of-use level was shown to be extremely effective. An independent samples T-test between Non-Treater and Treater londes showed a strong disparity in both $\mathrm{E}$. coli $(\mathrm{F}=14.781$, sig<0.001) and coliform $(F=23.941$, sig<0.001) colonies. 


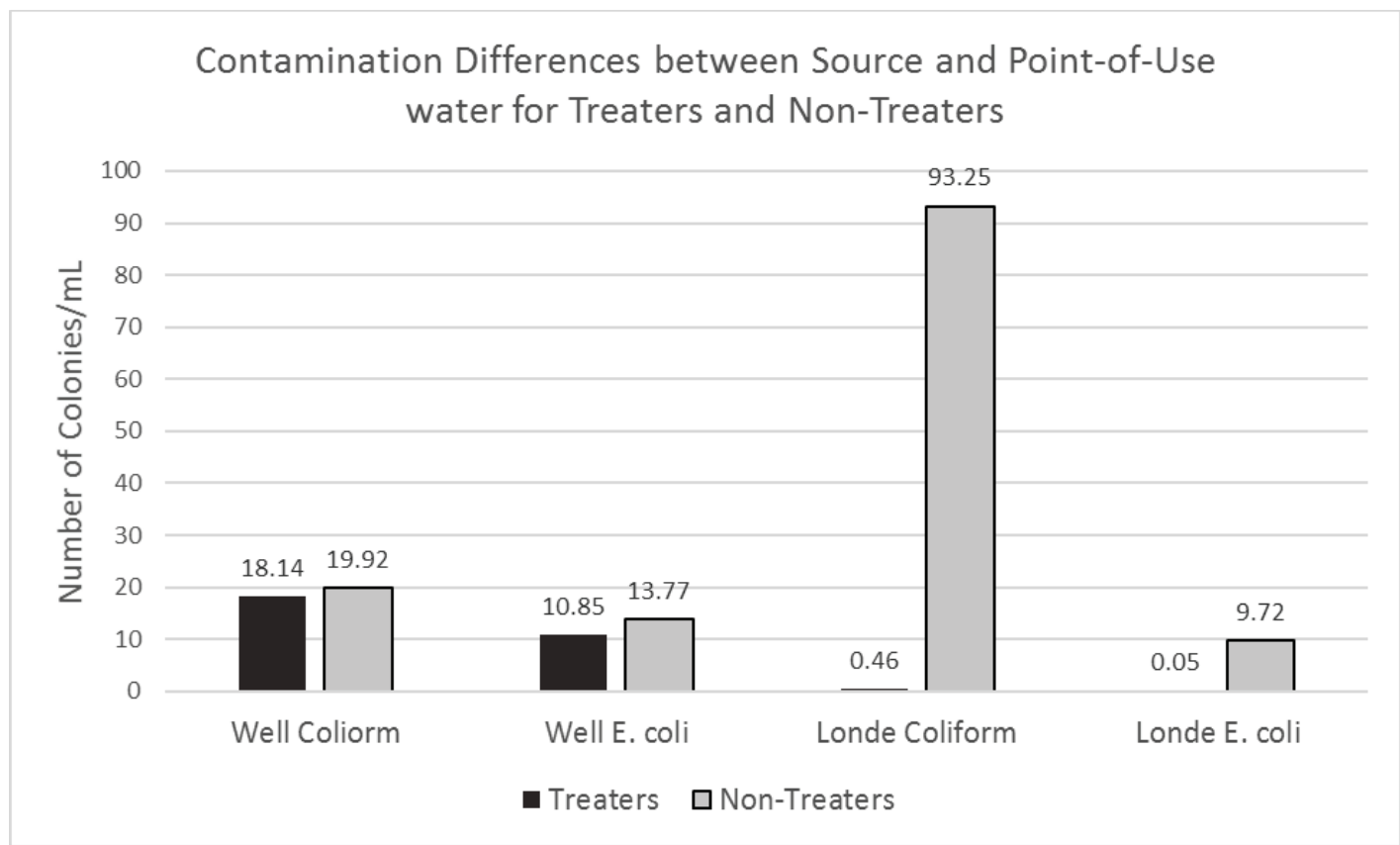

Figure 27: Average coliform and E. coli growth in the wells and londes of both Treaters and Non-Treaters. The average number of colonies/mL is shown above each column.

The bleach intervention lowered the Treaters' coliform and E. coli load enough that most Petrifilms $^{\mathrm{TM}}$ showed no growth at all (Figure 27 and Table 4). Wells utilized by Treaters and wells utilized by Non-Treaters had similar levels of coliform and E. coli contamination, but the londes of Non-Treaters had drastically higher coliform and E. coli counts than the treated londes did. Notice that the Treaters' londes had low enough coliform and E. coli colony counts that they are not perceptible on Figure 27.

If we look more closely at the wells and londes for individual Treaters and Non-Treaters, we see the same pattern. In Figure 28, the difference in coliform colonies between the well water and the londe water of Non-Treaters is striking. In 4 of the 12 cases (Dabo A, Sare Meta A, Sare Gueladio A, and Sare Gueladio B), the londes were over twice as contaminated with coliforms as the source wells were. Sare Gueladio Non-Treater A had the most coliform growth in her londe - 494 colonies $/ \mathrm{mL}$, which is 78 times the concentration of coliforms in her source well. Figure 29 shows the difference in $\mathrm{E}$. coli colonies between wells and londes of Non-Treaters. Unlike the coliforms, there were no situations where the londe water was significantly more contaminated than the source water.

In most of the Non-Treater cases, there was roughly the same contamination level in the well and in the londe. In these cases, the water did not become cleaner or more contaminated during storage. 


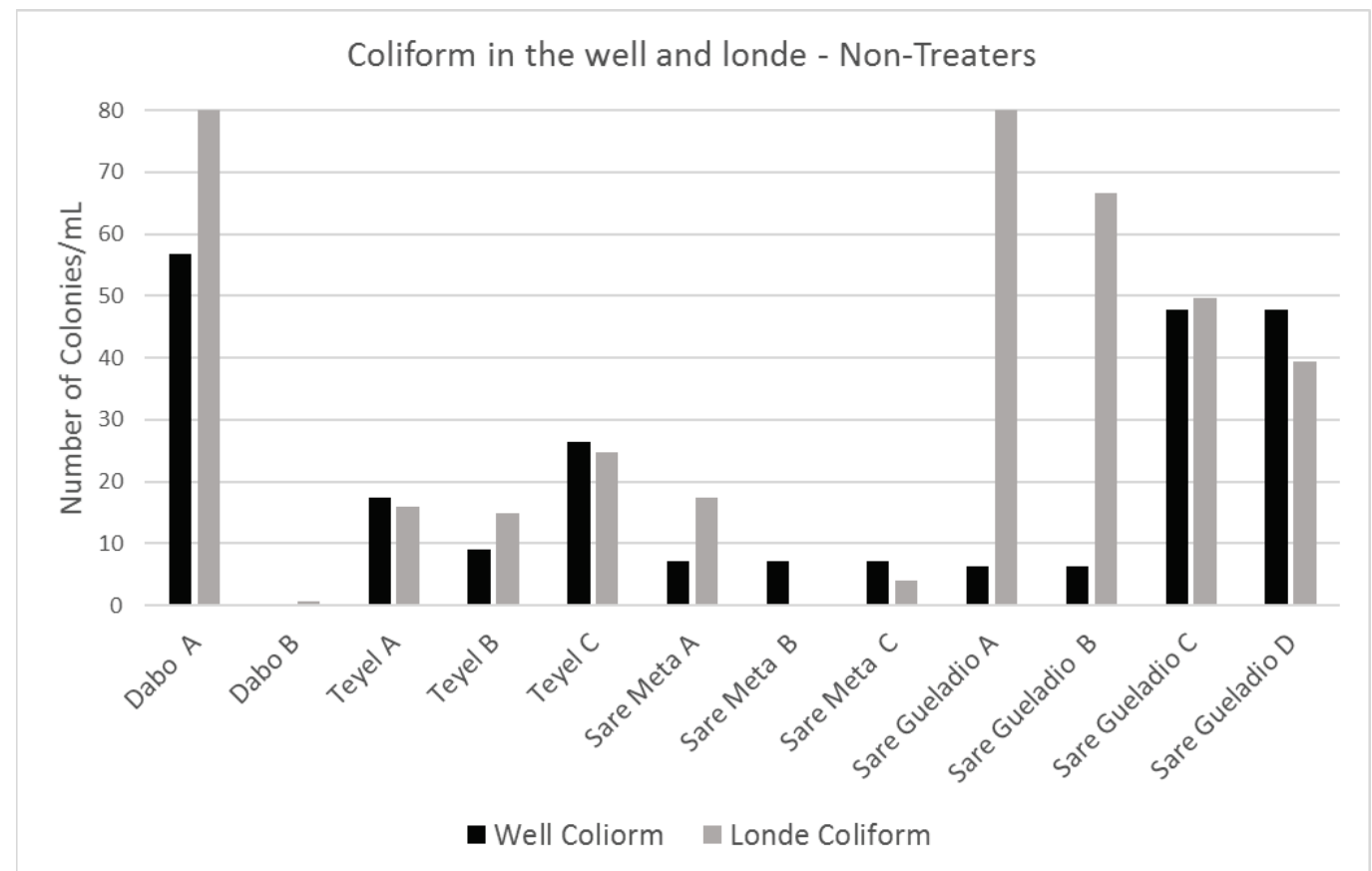

Figure 28: Source water (well) compared to point-of-use water (londe) for Non-Treaters (those who do not utilize a point-of-use water treatment). Two londe outliers are cut off - Dabo A, with 391 colonies $/ \mathrm{mL}$, and Sare Gueladio A, with 494. See appendices for full coliform and E. coli counts.

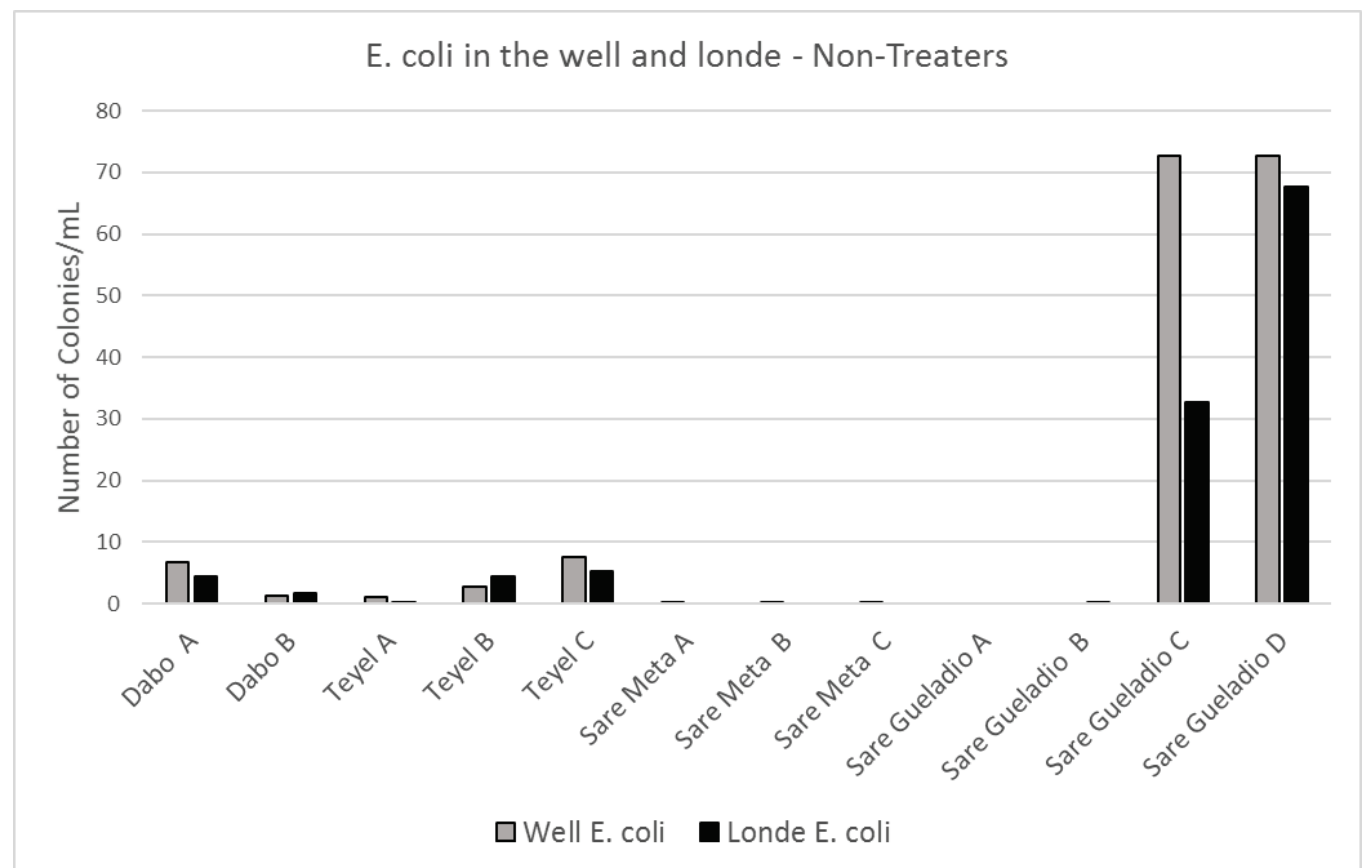

Figure 29: Source water (well) compared to point-of-use water (londe) for Non-Treaters (those who do not utilize a point-of-use water treatment.) 
Two Non-Treaters (Sare Meta B and Sare Gueladio C) had lower colony counts in their londes than the water at the source $(7.17$ coliform colonies at the source to 0.33 at pointof-use for Sare Meta B [Figure 28] and 72.67 E. coli colonies at the source to 32.67 at point-of-use for Sare Gueladio C [Figure 29]). This decrease amounts to a 21x reduction for Sare Meta B. Since the WHO standard for clean drinking water is 0 coliforms or $\mathrm{E}$. coli per $100 \mathrm{~mL}$ of water, water that has any contaminants at all is classified as unsafe. By this standard, all of the water in all of the Non-Treaters' londes is considered unfit for human consumption, even if it is bacteriologically cleaner than the water in the source well.

In contrast to the Non-Treaters' londes in Figures 28 and 29, we next look at the coliform and E. coli counts of the Treaters' londes in Figure 30. All wells utilized by the water Treaters had measurable coliforms in roughly the same numbers as in the wells of the Non-Treaters, and most contained small amounts of E. coli as well. However, Treater londes showed hardly any microbial growth (with the exception of Sare Gueladio A). See Table 4 and the appendices for more data on coliform and E. coli counts.

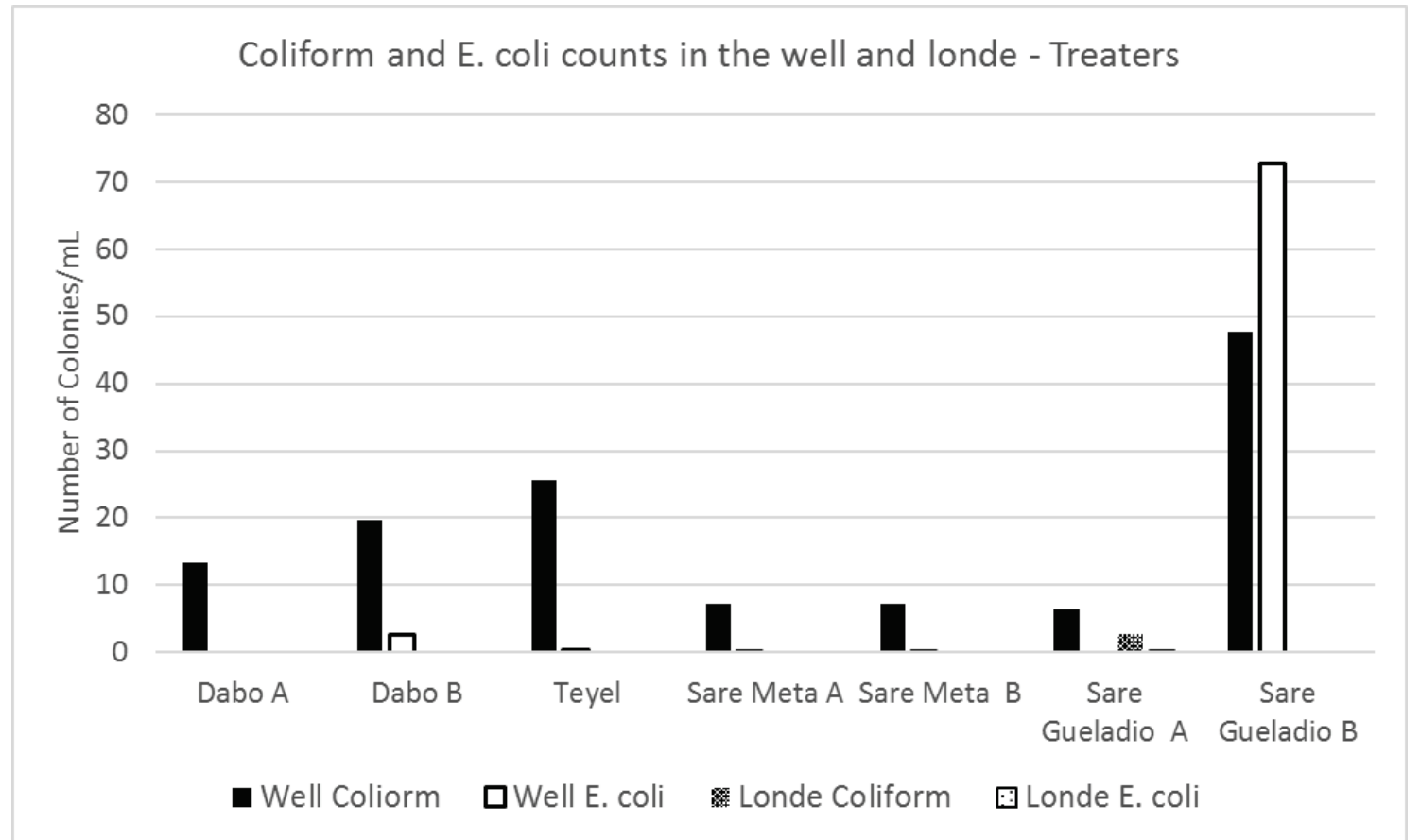

Figure 30: Source water (well) compared to point-of-use water (Londe) for both coliforms and E. coli for the Treaters (those utilizing the point-of-use bleach intervention). Note that there is no measurable coliform or $\mathrm{E}$. coli growth in the londes of most Treaters (With the exception of Sare Gueladio A).

Only one Treater, Sare Gueladio A, had enough bacterial colonies in her londe sample to show a perceptible bar in Figure 30 . However, Sare Gueladio A also used only $1 / 4$ to $1 / 2$ of the WHO recommended dosage of bleach ( $1 \mathrm{~mL}$ of bleach for $20 \mathrm{~L}$ of water). Table 4 shows the amount of bleach added to each Treater's londe and the corresponding coliform and E. coli colony counts. 
Table 4: Bleach added to Treaters' londes vs. coliform and E. coli counts.

\begin{tabular}{|l|l|l|l|}
\hline & $\begin{array}{l}\text { Amount of bleach }(\mathrm{mL}) \\
\text { that was added to the } \\
\text { londe (recommended } \\
\text { dose to treat 20L is } \\
2.11-4.22 \mathrm{~mL})\end{array}$ & $\begin{array}{l}\text { Coliform count (average } \\
\pm \text { standard error) }\end{array}$ & $\begin{array}{l}\text { E. coli count } \\
\text { (average } \pm \text { standard } \\
\text { error) }\end{array}$ \\
\hline Dabo A & 1 & $0.33 \pm 0.33$ & $0.00 \pm 0.00$ \\
\hline Dabo B & 5.5 & $0.00 \pm 0.00$ & $0.00 \pm 0.00$ \\
\hline Teyel & 3.5 & $0.20 \pm 0.20$ & $0.00 \pm 0.00$ \\
\hline Sare Gueladio A & 1 & $2.67 \pm 0.88$ & $0.33 \pm 0.33$ \\
\hline Sare Gueladio B & 2 & $0.00 \pm 0.00$ & $0.00 \pm 0.00$ \\
\hline Sare Meta A & 11 & $0.00 \pm 0.00$ & $0.00 \pm 0.00$ \\
\hline Sare Meta B & 3 & $0.00 \pm 0.00$ & $0.00 \pm 0.00$ \\
\hline
\end{tabular}

The amount of bleach used by the Treaters was variable (Figure 31 and Table 4). The majority of Treaters whose water was sampled fell within the WHO recommended dosage threshold of 8-16 drops per gallon (2.11-4.22 mL/20-liter londe - marked on Figure 31). The average bleach dosage for Treaters was $3.84 \mathrm{~mL} \pm 0.661$. If the outlier (Sare Meta A) is removed, the mean falls to $2.76 \pm 0.340$. Bleach use reported by the surveyed Treaters was greater than bleach use observed of sampled Treaters, though the difference was not significant. An independent samples t-test (variances not assumed) between bleach use reported on the surveys vs. bleach use measured during sampling: $\mathrm{t}=1.065$, sig 0.310 . 


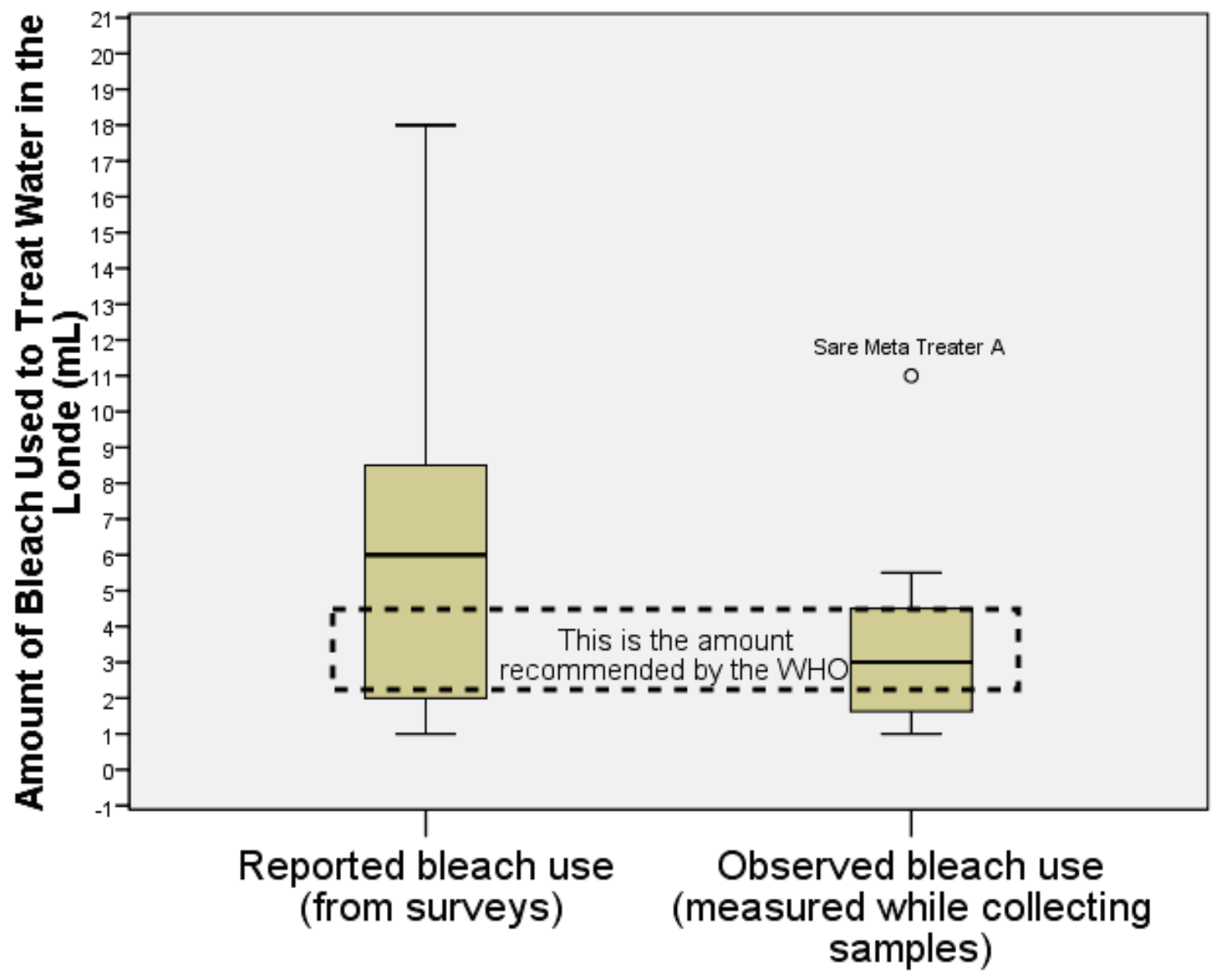

Figure 31: Comparison of reported bleach use in the surveys and measured bleach use of Treaters in the field. It was assumed that a survey answer of "two drops" was $1 / 2 \mathrm{~mL}$ and "three drops" was $1 \mathrm{~mL}$. It was also assumed that all "capfuls" referenced during the surveys were standard MADAR caps, $6 \mathrm{~mL}$ each. 


\section{DISCUSSION - SURVEYS}

The initial goal of the surveys was to examine differences between Koldans who treat their water and those who do not, and to use that information to target future behavior change projects for Non-Treaters in the region. However, when the surveys were analyzed, there were few significant differences between Treaters and Non-Treaters (see Appendix Table 5). As I conducted further literature review on changing health behaviors in developing countries, I found that this ambiguity is usually the case (Aboud, 2012). Qualitative surveys are a good way to determine known barriers to a behavior. However, the true barriers may be subconscious, and people may not realize the actual reasons behind their habits (Aboud, 2012). For the purposes of this report, I will share data that I found interesting or compelling, and in the "Ideas for Future Work" section of this report I will use the results to provide recommendations for future behavior change programming in the Kolda region of Senegal.

Although the surveyed Koldans did not cite knowledge about water treatment as a perceived barrier ( $94 \%$ of respondents said with their current knowledge, skills, and abilities they could treat their water with bleach), it was found that more education about the correct dose is nonetheless needed. Figures 15 and 31 show the wide variation in bleach amounts that water Treaters use for point-of-use treatment. Anecdotally, I think the measured values shown on Figure 31 and Table 4 are more accurate than the reported values on Figures 15 and 31 . The sampled londe that had $11 \mathrm{~mL}$ of bleach in it (Sare Meta Treater A) had such a strong taste and smell it was nearly undrinkable, and it is difficult for me to believe that anyone else regularly drinks water with such a strong chemical taste. The respondents that said they regularly use more than a capful of bleach (Figure 15) may have misunderstood the question, may have been using a different sized cap for measurement than a standard MADAR cap, or may have exaggerated their bleach use to please or impress their surveyor.

Although most Treaters and Non-Treaters said there were no disadvantages to water treatment with bleach, some respondents did say that bleach is bad for the body $(22 \%$ of respondents) and that bleach can taste bad (11\%). These concerns might be mitigated by modeling the proper dose of bleach in community demonstrations. Sare Meta Treater A had four times the recommended amount of bleach in his londe, but he believed that he had only used the dose necessary for treatment. His water did have a strong negative taste and smell, but he was strong enough in his convictions of the importance of clean water that he forced his family to drink it anyway. Once I showed him the correct dosage, he was happy to reduce his bleach usage to the recommended level. The majority of respondents who listed that bleach is bad for the body or tastes bad on survey question 5 (Figure 17) did report using the dosage recommended by the WHO.

The small percentage of the Koldan population that bleaches their water could be utilized as role models to encourage their neighbors to treat their own water. It is known that a very small proportion of Kolda's population bleaches their water (estimated to be 
$5 \%$ of the population or less based on data collected from other West African countries in Rosa 2010 and McMahon 2013). According to sociologist Everett Roger's landmark 1962 book Diffusion of Innovations, for every new behavior or idea in every population, approximately $2.5 \%$ of people are innovators. Innovators are unafraid to try new things and are open to unorthodox ways of thinking. Archetypical innovators value education and being the first to hear about a new product (Rogers, 1962). Kolda's water Treaters fit these characteristics.

Treaters were far more likely than Non-Treaters to say they desired knowledge the most in life (Figure 21). If Treaters desire knowledge most in life, they would probably be enthusiastic about learning, making them an ideal audience for Peace Corps Volunteers to teach water, sanitation, and hygiene behaviors to. When asked who would disapprove of chemical water treatment, "People who don't know" was the second-most popular answer for Treaters and Non-Treaters alike (Figure 20), implying that bleach use was positively associated with knowledge by Treaters and the Non-Treaters alike. Since the Treaters were more likely to say no one would disapprove of them treating their water (Figure 20), Treaters might be willing to go public with their bleach use and become public spokespeople of chemical water treatment in their communities. Stereotypical innovators are outgoing and have high social status (Rogers, 1962). If the Treaters in Kolda share these characteristics, they might thrive in a leadership role passing along health messages that would lead to greater water safety practices in the population as a whole.

Figure 22 lists a wide variety of perceived potential causes of diarrhea. Most of the perceived causes for diarrhea in McMahon's (2013) Sierra Leone study were also brought up by the Koldan population (contaminated food/water and eating bad food). However, in McMahon (2013) the number of people who answered each way was not quantified - it was simply listed whether each cause was mentioned or not, and by whom, so the percentage of the population that believes each cause cannot be compared between the Koldan and Sierra Leonean populations. The most commonly cited cause of diarrhea in Kolda was "bad water" (Figure 22), but since only half of all respondents answered this way and the respondents were free to list as many causes as they could think of, it is far from a consensus. The large number of people who answered "bad water" might also have been influenced by the fact that the question was asked near the end of the survey (Table 1) and water had been a pertinent topic throughout; the respondents may have responded that bad water causes diarrhea simply because they wanted to answer the question "correctly." More research is needed to examine perceived diarrhea causes in Kolda and how those perceived causes relate to behavioral health choices in the population.

The majority of respondents (88\%) reported that it would be "very serious" if they or the children got diarrhea (Figure 23). This implies that Koldans know diarrhea can kill in severe cases - however, less severe diarrheal disease can sometimes be seen as an unavoidable, common, inevitable part of childhood. A study done in Kenya in 2007 
showed that $43 \%$ of caretakers of children under five believed that diarrhea in children is impossible to prevent - it is just a normal part of growing up (Curtis, 2009). On Figure 23, "bad water" was cited by only half of respondents as a potential cause of diarrhea, meaning that the perceived association between untreated water and diarrhea is not strong in the population. The $14 \%$ of Non-Treaters who responded that they were not likely to get diarrhea from drinking untreated water (Figure 24) may regularly drink untreated water without having any problems with it, or perhaps they see the resulting diarrhea as normal and unavoidable, regardless of what kind of water they drink. 


\section{DISCUSSION - PETRIFILMS TM}

All of the 11 wells sampled were contaminated to some extent with coliforms and/or E. coli. This high well contamination level was expected and agrees with other literature done on unprotected wells in developing countries. In Colombatti's (2009) study in Guinea Bissau in 2006, all 12 water sources studied showed significant bacteriological contamination. Since the samples for this study were collected in February and March, which is the dry hot season in Senegal, it's expected that sampled E. coli and coliform counts were at their lowest annual concentrations. When the rains come (usually from July to October), the previous year's fallen livestock excreta can leach into the aquifer, as the soil is sandy and the wells are not deep (Gelinas 1996). It might be for this reason that some survey respondents reported using bleach to treat their water only in the rainy season (Figure 16).

The observed difference in contamination level between lined and unlined wells was also expected and agrees with the literature. Cement lined wells are deeper, which was positively correlated with cleanliness in Gelinas et al (1996). The well's cement lining is known to help prevent soil particles, worms, and insects from entering the water. Although cement-lined wells usually have better water quality than unlined wells, all sampled wells were still contaminated by the WHO guidelines. It would be expensive and time-consuming to cement-line all wells, and the resulting water would probably still not be considered safe to drink by the WHO threshold of 0 colonies $/ 100 \mathrm{~mL}$.

Adding bleach to the londe was shown to significantly and dramatically decrease its microbial contamination load. Almost half of the sampled Treaters added less bleach to their londes than WHO recommendation (Figure 31 and Table 4), and there was still a drastic difference in microbial load when compared to water that had not been treated (Figures 27, 28, 29, and 30, and Table 4).

Of the seven Treaters, six had londe coliform counts significantly decreased from their source water (see Table 5). Sare Gueladio Treater B, the individual who did not have significantly decreased counts, used the smallest amount of bleach of any Treater - only $1 \mathrm{~mL}$ (Table 4), roughly $1 / 4$ to $1 / 2$ as much as she should have used according to the WHO recommended dosage guidelines. When I tasted her treated water during sampling, the bleach was imperceptible. Although this very small amount of bleach at the point-of-use level was not adequate to make her water significantly less contaminated than her source water, her water was still much cleaner than the two people who got their water from the same well and did not treat it (Sare Gueladio Non-Treaters A and B, with 494 and 67 average coliforms $/ \mathrm{mL}$, respectively - see appendix Table 6)

In 4 of the 12 non-treater londes (Dabo Non-Treater A, Sare Meta Non-Treater A, and Sare Gueladio Non-Treaters A and B), the londe water had over twice as much coliform or E. coli bacteria than the water at the source did (Table 5). This phenomenon is common in the literature - Wright 2004, Seib 2011, Mellor 2013, and Mengistie 2013 all 
showed that water faces a decline in quality during storage (after collection but before consumption). The increase in contamination was shocking in some cases. Sare Gueladio Non-Treater A's water went from 6.33 coliform colonies $/ \mathrm{mL}$ at the source to 494.33 at point-of-use -- a 78 fold increase.

Studies by Trevett (2005) and Mellor (2013) outlined possible mechanisms for increased contamination at point-of-use. Trevett and Mellor both found that water quality degradation could result from dirty hands, with $96 \%$ of hands being containing coliform CFUs in Mellor's study. It is certainly feasible that the contamination in Koldan londes is due to contamination from hands, especially from children. In my experience in Senegal, it was rare to observe adults fetching their own drinking water from the londe. Since it is a patriarchal, age-stratified society, older people expect younger people to fetch water for them. Children scarcely able to walk (who likely have dirtier hands than adults) would be sent to fetch water from the londe and to deliver it to their elders (Figure 6). Both Trevett's (2005) and Mellor's (2013) studies also found fecal coliforms present on well buckets and londe cups, and Trevett speculated that filter cloths stored in unhygienic conditions may also be a source of contamination. Mellor (2013) conducted an incubation experiment of stored water at the household level in South Africa and found that coliform CFUs in the samples could increase dramatically during storage even in the absence of human interference.

In two occasions for the Non-Treaters, the bacterial concentration of the londe was lower than that of the source water. Sare Meta Non-Treater B's londe had a lower coliform count than the water at the source (7.17 colonies at the source to 0.33 at point-of-use), and Sare Gueladio Non-Treater $C$ had a lower E. coli count (72.67 colonies at the source to 32.67 at point-of-use). It is unknown what caused these results. Sare Meta Non-Treater B and Sare Gueladio Non-Treater C did not appear to be different from other londes. Since only two of the 12 londes sampled were cleaner at point-of-use than the water at the source, the change was not drastic, and there is no obvious reason for the results, no recommendations can be made on filtering or londe maintenance behavior for water cleanliness at the point-of-use level, though of course londes should be kept as clean as possible. 


\section{SUGGESTIONS FOR FUTURE WORK}

Results of this study and a review of available literature led to the following ten suggestions for future drinking water treatment projects in the Kolda region of Senegal.

1. Those that already treat their water should be utilized as facilitators when possible. Since most communities had at least a few people who treat their water, these innovative Treaters should have an important role in planning and delivering programming to help spread the practice. Treaters face the same barriers to behavior change that Non-Treaters do, but Treaters have overcome those barriers. Research has shown that having local facilitators is more effective than having foreigners lead programming activities (Figueroa 2010). Locals' speech is easier to understand, they share common beliefs and understandings with their neighbors, and they are less likely to make cultural gaffes. Treaters tended to value knowledge (Figure 21) and were more likely to say that no one disapproved of them treating their water (Figure 20). If the Treaters follow the stereotypes of typical innovators in Rogers' Diffusion of Innovations (1962), they will be curious, social, confident, and popular in their communities - ideal work counterparts for Peace Corps Volunteers.

2. Future programming should focus on making water treatment a habit. Since research has shown that up to $50 \%$ of a behavior is habitual (Curtis et al 2009), future volunteers should work with local populations to establish treating water at the point-of-use level as a routine. The survey results underscore the importance of this. When asked what would make it easier to treat their water, more Treaters than non-Treaters said "being used to it" would help (Figure 18). This implies that the Treaters may have forgotten to treat their water in the past even though they intended to do it. Peace Corps Volunteers could stick to tried-and-true memory techniques to help aspiring Treaters remember to bleach their water, such as tying a string around their finger, having an "accountability buddy" check in every morning until treatment becomes routine, or putting the bleach bottle near the londe as a visual reminder cue. Some research shows that new mothers might be an ideal target audience for working at changing habitual behaviors, since they may be biologically predisposed to be more accepting of change (Rosenblatt 1994). The overwhelming majority of Treaters said "nothing" would make it easier for them to treat their water (Figure 18), implying that once they're used to it, it's a simple process.

3. Volunteers should keep pushing for a more highly regulated water treatment product to be made available. The 2010 USAID promotion of Aquatabs ${ }^{\mathrm{TM}}$ at the Magal festival in Senegal shows that Aquatabs ${ }^{\mathrm{TM}}$, when available, can have great successes in minimizing diarrheal disease (Gambrill 2013). In addition to Aquatabs $^{\mathrm{TM}}$, NGO programs throughout Africa have long promoted highly regulated diluted bleach products specialized for water treatment (e.g., CLARO, 
Sûr'Eau, Clorin, and Aguo Pura, among others) (Mintz 2001). Makutsa and Nzaku (2001) showed that adoption rates for one water treatment product, Water Guard $^{\mathrm{TM}}$, were as high as $70 \%$ in some Kenyan villages where it was introduced. The water treatment products have clear pictorial dosing instructions for a largely illiterate population, and are easy to dose with - the Aquatabs ${ }^{\mathrm{TM}}$ are dosed so that one tablet is adequate for a $20 \mathrm{~L}$ water storage container, and the liquid products include a calibrated cap for measuring out the correct dosage. So far, all these products are dependent on NGOs for production and distribution, but it may be possible for a water treatment product to be produced and sold locally. If the product is marketed effectively and sold for a fair price, its production could be a source of revenue for everyone involved in the manufacture.

4. Volunteers should demonstrate proper water treatment technique in demonstrations or classes. Until piped water is available for all of Kolda's residents, or at least until highly regulated household water treatment products are available in Senegal, normal boutique bleach will have to do. The Peace Corps framework recommends 8-16 drops per gallon, which works out to 2.11$4.22 \mathrm{~mL} / 20$-liter londe, but measuring equipment is widely unavailable in resource-poor areas. In the surveys done for this project, most people who treated their water claimed that they put in one capful of bleach, which measures out to be $6 \mathrm{~mL}$ : more than the recommended dose. Some survey respondents claimed they put in three or more capfuls. Although over-bleaching water is probably not harmful (see "Difficulties and Drawbacks of Bleach - Dangers" section), it does make the water taste and smell terrible, which may cause people to abandon water treatment altogether. Since measuring devices to ensure correct dosing are not common in the field, Peace Corps Volunteers should demonstrate what the correct dose looks like in the bleach bottle cap and should demonstrate what correctly dosed water tastes and smells like. When I did this with Sare Meta Treater A, who had formerly used quadruple the recommended dosage $(11 \mathrm{~mL})$, he was receptive to changing his behaviors. Demonstrating proper dosage could help spread the practice to Non-Treaters, as well. If NonTreaters taste properly treated water, they may find that it's not that bad. In fact, they may actually like the taste and smell. Four of the surveys (4\%) said that improved taste was an advantage to chemical water treatment.

5. Volunteers should be flexible with their expectations and should encourage even small amounts of bleach use. Some Treaters whose water was sampled for this report used a very small, barely perceptible amount of bleach in their londes and still saw decreases in bacterial contamination (Table 4). The WHO does not consider water to be clean unless it is $100 \%$ bacteria free, but even if that threshold is not reached, there are still health benefits of reduced bacterial load in the drinking water. Most bacterial diarrheal diseases are dose dependent (Huq 2010), so merely decreasing the bacteria may prevent the onset of diarrhea. If community members balk at the perceived negative effects of adding a lot of 
bleach to their londes, it would still be beneficial to add some. Sare Gueladio Treater A and Dabo Treater A both put in half the minimum dose recommended by the WHO, and both had declines in coliforms and $\mathrm{E}$. coli in their water. The declines might be enough to prevent individuals in their families from getting sick after drinking the water.

6. Avoid overdramatizing negatives of not treating water. Fear mongering is not an effective behavior change strategy for preventative health behaviors because the effects of preventative interventions are not clear and immediate. A healthy adult who has never treated their water would likely be skeptical toward claims that untreated water is lifethreateningly dangerous for themselves or their children, especially if water treatment is uncommon throughout the community; if no one treats their water, there is no urgency to start. If diarrhea is common in the community, it may be seen as normal and unavoidable, and therefore not worthy of taking action against. Only half of respondents in the surveys for this report thought that

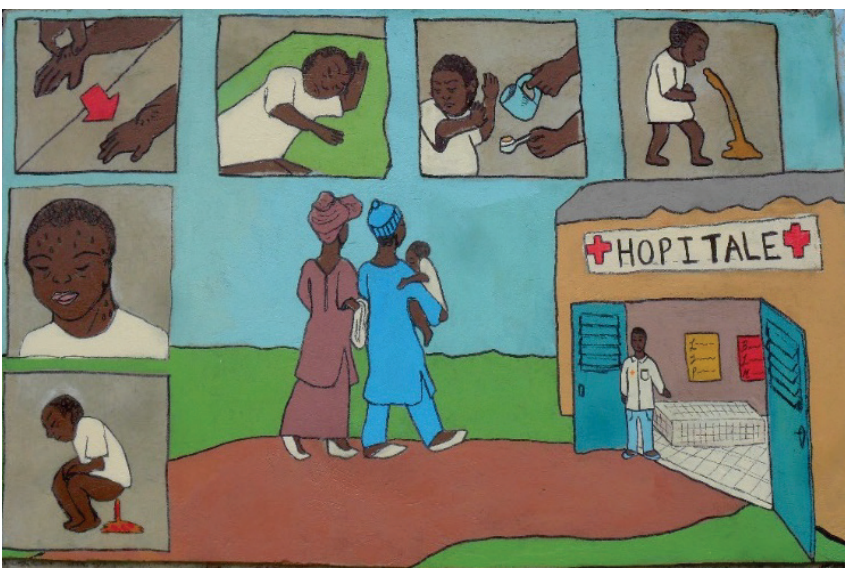

Figure 32: Mural done by the author showing Danger Signs of Diarrhea. Such murals might actually decrease diarrheal careseeking behaviors, as they imply that subtler diarrheal cases that do not involve these Danger Signs are "normal" and not worthy of preventative measures.

"bad water" was a possible cause of diarrhea when they were asked to list as many causes as they could think of (Figure 23) and Figure 24 demonstrates that there is a considerable subset of Non-Treaters who thought it was "not likely at all" that drinking untreated water would cause diarrhea. Since these individuals don't recognize or appreciate the link between untreated water and diarrhea, scaring them with statistics about deaths caused by diarrhea would not be effective. The Non-Treaters may agree that diarrhea is unpleasant, but they do not think their choice of drinking water could contribute to diarrhea. They may think that diarrhea they or their children are experiencing is normal, not worthy of medical attention like the extreme cases illustrated on Figure 32. Instead of dramatizing diarrheal threats, volunteers could focus on highlighting positive outcomes of treating water, such as "bringing health." Figure 21 illustrates that water Treaters were more likely than Non-Treaters to say that good health is a reason to chemically treat their water with bleach. Since health was found to be the most common universal motivator in the surveyed population (Figure 22) the message that clean water brings health should continue to be utilized in behavior change programming, especially for potentially vulnerable members of the population, such as children and the elderly. Since $21 \%$ of respondents said 
"people who are not educated" disagree with treating their water (Figure 20), some social marketing could be done to promote bleach treatment as something that smart, educated, forward-thinking people do when they value their own and their children's health.

7. If necessary, address the Perceived Access Barrier in the community. In three communities surveyed for this research, the majority of respondents said it was "very difficult" to obtain materials needed to treat water; however, in each of those communities, at least one respondent said it was "not difficult at all" to access materials. Perhaps a person from each community who does not find it difficult to acquire bleach could volunteer to stock up on the product and sell it out of their home. This process is already common in Senegal. In small villages, there are usually a few individuals that stockpile tea, biscuits, oil, and rice and sell these products to their neighbors. It would be reasonable for them to do the same thing with bleach. It might also be feasible in small villages or tight-knit neighborhoods in larger communities to have several villagers each pay a portion of the cost of a bottle of bleach, then have someone circulate the village every morning or evening, when londes are filled, adding the correct dose of bleach for everyone who contributed.

8. More work needs to be done to promote treating water at the point-of-use level instead of treating the well water directly. As a Peace Corps volunteer, I was regularly told by my community that bleaching the wells is actually better than bleaching the londes, because wells are used for water for showering and laundry, too, and it's important that the water be clean for those activities as well as for drinking. Indeed, Figure 23 shows that "dirtiness/bad hygiene" was the third most popular mentioned cause of diarrhea, right after "bad water" and "contaminated food." If it is believed that bleach cleans water and showering with unclean water causes diarrhea, it is logical that Koldans would view bleaching water at the well level as an important health precaution. There also seems to be a gap in knowledge amongst Koldans about how long the intervention of bleaching the wells lasts. In Rowe (1998), villagers in Guinea Bissau responded that bleaching their wells would protect the water for between two weeks and six months, and many people in Kolda also seem to be under the impression that if a well is bleached, it retains cleanliness for a long time, as displayed by the $50 \%$ of survey respondents who bleach their water once a week or less (Figure 16). However, research shows that bleached well water can become re-contaminated quickly, and sometimes it never reaches an adequate free chlorine level at all (Rowe 1998, Cavallaro et al, 2011). Since widespread contamination of wells in developing countries is so common both in the literature (Luby 2006 and Colombatti 2009) and in the water sampling done for this project (Figure 25), it is likely that the aquifers themselves are contaminated to some degree, and treating water in the well would have a limited effect. Future volunteers might promote behavioral change from well bleaching to londe bleaching by 
emphasizing the fact that treating water at the point-of-use level is just as easy as treating the well, and it's far cheaper -- since the amount of water being treated is so much less in the londe, less bleach needs to be used. If a $20 \mathrm{~L}$ londe is bleached as directed by the WHO guidelines of $3 \mathrm{~mL}$ a day, a $500 \mathrm{~mL}$ bottle of bleach will last for 166 londe refills. Since "money" was the second-mostcommon universal motivator (Figure 22) with $29 \%$ of respondents saying they desired money more than anything else in life, this economic boost would likely be appreciated.

9. Target future programming not only to mothers, but also fathers, brothers, sisters, and grandparents. Often, Peace Corps Volunteers work with mothers of children under five because the mothers provide the most direct care to the children (ie, feeding, clothing, bathing). However, in a patriarchal society like a traditional village in Kolda, some mothers might not be empowered in the home to actually implement water treatment behaviors on their own. Usually, it is the men who control finances in the home, so if the men refuse to purchase bleach for water treatment, treatment cannot occur. More men seem to agree with treatment than disagree. When respondents were asked who disapproves with water treatment, $5 \%$ of surveys listed men, but when asked who approves, nearly twice as many $(9 \%)$ had the same answer $(0 \%$ of surveys said women disapprove of bleaching and $8 \%$ said they approve.) In traditional households, elders might have the final say in household decisions. Since $6 \%$ of survey respondents said old people disapprove of water treatment (Figure 20), and 0\% of surveys said old people approve, it may be necessary to gain elder approval before the practice can take root in a particular household. Treaters in this research were more likely than Non-Treaters to say that "no one" disapproves of them treating their water (Figure 20). If treating water were more socially acceptable for all people in the entire community, more people might be more likely to do it. Water treatment should be encouraged for all members of the population to aid its acceptability.

10. Other sanitation behaviors (such as handwashing and latrine use) should continue to be addressed. Since there are many causes of diarrhea, all aspects of water, sanitation, and hygiene must be considered to have the largest impact on diarrheal morbidity. Water treatment using bleach may well lead to a decrease in diarrheal disease, but for true progress it cannot stand alone. Water treatment practices should be encouraged in parallel to other sanitation and hygiene behaviors. 


\section{WORKS CITED:}

"Effect of Chlorination on Inactivating Selected Pathogens." Centers for Disease Control and Prevention. Centers for Disease Control and Prevention, 21 Mar. 2012. Web. 13 Nov. 2016. <http://www.cdc.gov/safewater/effectiveness-onpathogens.html>.

"Under-Five Mortality - UNICEF DATA." UNICEF DATA. UNICEF.org, Oct. 2016. Web. 07 Oct. 2016. <https://data.unicef.org/topic/child-survival/under-fivemortality/>.

Aboud, Frances E., and Daisy R. Singla. "Challenges to changing health behaviours in developing countries: a critical overview." Social science \& medicine 75.4 (2012): 589-594.

Agence Nationale De La Statistique Et De La Démographie (ANSD) De Kolda, Senegal. Ministere De L'economie, Des Finances, Et Du Plan. Situation Economique Et Sociale Regionale 2013.

Agence Nationale de la Statistique et de la Démographie (ANSD) [Senegal], and ICF International. 2012. Senegal Demographic and Health and Multiple Indicator Cluster Survey (EDS-MICS) 2010-2011. Rockville, Maryland, USA: ANSD and ICF International.

Agence Nationale De La Statistique Et De La Démographie (ANSD), Senegal. Ministere De L'economie et Des Finances. Les Disparites Geographiques De L'acces aux Services Sociaux de Base au Senegal: Enquete-villages 2000 et 2009. Septembre 2011.

Arnold, Benjamin F., and John M. Colford. "Treating water with chlorine at point-ofuse to improve water quality and reduce child diarrhea in developing countries: a systematic review and meta-analysis." The American journal of tropical medicine and hygiene 76.2 (2007): 354-364.

Arvai, Joseph, and Kristianna Post. "Risk Management in a Developing Country Context: Improving Decisions About Point

the Rural Poor in Africa." Risk Analysis 32.1 (2012): 67-80.

Brunner, Bettina, Jeffrey Barnes, Andrew Carmona, Arsène Kpangon, Pamela Riley, Erin Mohebbi, and Leslie Miles. 2016. Senegal Private Health Sector Assessment: Selected Health Products and Services. Bethesda, MD: Strengthening Health Outcomes through the Private Sector Project, Abt Associates.

Cavallaro, Elizabeth C., et al. "Evaluation of pot-chlorination of wells during a cholera outbreak, Bissau, Guinea-Bissau, 2008." Journal of water and health9.2 (2011): 394-402.

Central Intelligence Agency. "The World Factbook: SENEGAL." Central Intelligence Agency, n.d. Web. 07 Oct. 2016. <https://www.cia.gov/library/publications/theworld-factbook/geos/sg.html>. 
Clasen, Thomas, and Paul Edmondson. "Sodium dichloroisocyanurate (NaDCC) tablets as an alternative to sodium hypochlorite for the routine treatment of drinking water at the household level." International journal of hygiene and environmental health 209.2 (2006): 173-181.

Colombatti, R., et al. "Contamination of drinking water sources during the rainy season in an urban post-conflict community in Guinea Bissau: implications for sanitation priority." African Journal of Medicine \& Medical Sciences 38.2 (2009): 155-161.

Colwell, Rita R., et al. "Reduction of cholera in Bangladeshi villages by simple filtration."Proceedings of the National Academy of Sciences100.3 (2003): 1051-1055.

Curtis, Valerie A., Lisa O. Danquah, and Robert V. Aunger. "Planned, motivated and habitual hygiene behaviour: an eleven country review." Health Education Research 24.4 (2009): 655-673.

Environmental Protection Agency. USA. Water Health Series: Filtration Facts. 2005.

Eykelbosh, Angela J. "Review of Guidelines for Shock Chlorination in Private Wells." National Collaborating Centre for Environmental Health, NCCEH Evidence Reviews (2013).

Figueroa M.E., \& Kincaid D.L. (2010). Social, Cultural and Behavioral Correlates of Household Water Treatment and Storage. Center Publication HCl 2010-1: Health Communication Insights, Baltimore: Johns Hopkins Bloomberg School of Public Health, Center for Communication Programs.

Freese, S. D., and D. J. Nozaic. "Chlorine: Is it really so bad and what are the alternatives." Water Sa 30.5 (2004): 18-24.

Gambrill, A., and C. Zeilberger. "On the Waterfront: Overcoming Challenges."Global Waters. USAID, 04 Sept. 2013. Web. 11 Oct. 2016.

<https://www.usaid.gov/global-waters/september-2013/on-the-waterfront>.

Garenne, Michel, and Oliver Fontaine. "Assessing probable causes of death using a standardized questionnaire: a study in rural Senegal." (1990): 123-42.

Gélinas, Yves, et al. "Well water survey in two districts of Conakry (Republic of Guinea), and comparison with the piped city water." Water Research 30.9 (1996): 2017-2026.

Guidelines for drinking-water quality, 2nd ed. Vol.2. Health criteria and other supporting information. World Health Organization, Geneva, 1996.

Harley, Earl H., and Millicent D. Collins. "Liquid household bleach ingestion in children: a retrospective review." The Laryngoscope 107.1 (1997): 122-125. 
Hrudey, Steve E. "Chlorination disinfection by-products, public health risk tradeoffs and me."Water research 43.8 (2009): 2057-2092.

Huq, Anwar, et al. "Simple sari cloth filtration of water is sustainable and continues to protect villagers from cholera in Matlab, Bangladesh."MBio 1.1 (2010): e00034-10.

Inungu, Joseph N., et al. "Factors Associated with the Uptake of Sodium Dichloroisocyanurate (NaDCC) Tablets as Household Water-Treatment Product among Caregivers of Children under Five in Benin, West Africa." Journal of Health and Human Services Administration 39.1 (2016): 121.

Kittle, Bonnie. 2013. A Practical Guide to Conducting a Barrier Analysis. New York, NY: Helen Keller International.

Lantagne, Daniele S. "Viability of commercially available bleach for water treatment in developing countries." American journal of public health 99.11 (2009): 19751978.

Luby, S., Md S. Islam, and R. Johnston. "Chlorine spot treatment of flooded tube wells, an efficacy trial." Journal of applied microbiology 100.5 (2006): 11541158.

Makutsa, Philip, et al. "Challenges in implementing a point-of-use water quality intervention in rural Kenya." American Journal of Public Health 91.10 (2001): 1571-1573.

McMahon, Shannon A., et al. "Spoiled breast milk and bad water; local understandings of diarrhea causes and prevention in rural Sierra Leone." BMC public health 13.1 (2013): 1.

Mellor, Jonathan E., et al. "Coliform sources and mechanisms for regrowth in household drinking water in Limpopo, South Africa." Journal of Environmental Engineering 139.9 (2013): 1152-1161.

Mengistie, Bezatu, Yemane Berhane, and Alemayehu Worku. "Household water chlorination reduces incidence of diarrhea among under-five children in rural Ethiopia: a cluster randomized controlled trial." PloS one 8.10 (2013): e77887.

Nossiter, Adam. "Cholera Epidemic Envelops Coastal Slums in West Africa."The New York Times 23 Aug. 2012, A6 sec.: n. pag. The New York Times. 22 Aug. 2012. Web. 09 Oct. 2016. $<$ http://www.nytimes.com/2012/08/23/world/africa/cholera-epidemic-envelopscoastal-slums-in-west-africa.html? $\quad \mathrm{r}=0>$.

Peace Corps Senegal community health project framework. <https://docs.google.com/file/d/0BxQg5Mxn-CTpNFZTckdIUUtOQTg/edit>

"Peace Corps." Senegal. N.p., n.d. Web. 13 Oct. 2016. $<$ https://www.peacecorps.gov/senegal/>. 
Practical Action Consulting, enda, and The World Bank. Baseline and feasibility assessment for alternative cooking fuels in Senegal. May 2014.

Rogers, Everett M. Diffusion of Innovations. New York: Free of Glencoe, 1962. Print.

Rosa, Ghislaine, and Thomas Clasen. "Estimating the scope of household water treatment in low-and medium-income countries." The American journal of tropical medicine and hygiene 82.2 (2010): 289-300.

Rosenblatt, J. S. "Psychobiology of maternal behavior: contribution to the clinical understanding of maternal behavior among humans." Acta paediatrica 83.s397 (1994): 3-8.

Rowe, Alexander K. "Chlorinating well water with liquid bleach was not an effective water disinfection strategy in Guinea-Bissau." (1998): 339-340.

Seib, Mathew D. "Assessing drinking water quality at source and point-of-use: a case study of Koila Bamana, Mali, West Africa." Master's Report, Michigan Technological University (2011).

Steiner, MD, Ted S., Nathan M. Thielman, MD, and Richard L. Guerrant, MD. "Protozoal agents: what are the dangers for the public water supply?."Annual review of medicine 48.1 (1997): 329-340.

Sugawa, Choichi, and Charles E. Lucas. "Caustic injury of the upper gastrointestinal tract in adults: a clinical and endoscopic study." Surgery106.4 (1989): 802-6.

Trevett, Andrew F., Richard C. Carter, and Sean F. Tyrrel. "Mechanisms leading to post-supply water quality deterioration in rural Honduran communities." International journal of hygiene and environmental health 208.3 (2005): 153161.

Unicef and World Health Organization. USA. 25 Years Progress on Sanitation and Drinking Water: 2015 Update and MDG Assessment. 2015.

World Health Organization. Guidelines for drinking-water quality: recommendations. Vol. 1. World Health Organization, 2004.

Wright, Jim, Stephen Gundry, and Ronan Conroy. "Household drinking water in developing countries: a systematic review of microbiological contamination between source and point

-"dfropical Medicine \& International Health 9.1 (2004): 106-117. 


\section{APPENDICES}

Table 5: Answers for Barrier Analysis Survey. Bolded values are significant at the 0.05 level using a Pearson's Chi-Square test between Treaters and Non-Treaters.

\begin{tabular}{|c|c|c|c|c|}
\hline Question Asked & Responses & $\begin{array}{l}\text { Treaters } \\
(\mathrm{N}=46)\end{array}$ & $\begin{array}{l}\text { Non- } \\
\text { Treaters } \\
(\mathrm{N}=51) \\
\end{array}$ & $\begin{array}{l}\text { Total } \\
(\mathrm{N}=97)\end{array}$ \\
\hline \multirow{3}{*}{$\begin{array}{l}\text { 1. With your } \\
\text { present knowledge, } \\
\text { money, and skills, } \\
\text { do you think you } \\
\text { could treat your } \\
\text { water with bleach? }\end{array}$} & Yes & 46 & 45 & 91 \\
\hline & Possibly & 0 & 2 & 2 \\
\hline & No & 0 & 4 & 4 \\
\hline \multirow{6}{*}{$\begin{array}{l}\text { 2. What } \\
\text { (makes/would } \\
\text { make) it easier for } \\
\text { you to treat your } \\
\text { water with bleach? }\end{array}$} & Having Bleach & 17 & 23 & 40 \\
\hline & $\begin{array}{l}\text { Having a filter, cloth, clean well, } \\
\text { cover, cap, etc. }\end{array}$ & 12 & 13 & 25 \\
\hline & Nothing & 18 & 3 & 21 \\
\hline & Having Money & 6 & 10 & 16 \\
\hline & $\begin{array}{l}\text { Knowledge about dosing and } \\
\text { importance }\end{array}$ & 2 & 5 & 7 \\
\hline & Being used to it & 5 & 1 & 6 \\
\hline \multirow{5}{*}{$\begin{array}{l}\text { 3. What } \\
\text { (makes/would } \\
\text { make) it more } \\
\text { difficult for you to } \\
\text { treat your water } \\
\text { with bleach? }\end{array}$} & Lack of money & 17 & 26 & 43 \\
\hline & Lack of bleach & 14 & 16 & 30 \\
\hline & Nothing & 16 & 6 & 22 \\
\hline & Lack of knowledge & 8 & 11 & 19 \\
\hline & $\begin{array}{l}\text { Lack of filter, cloth, clean well, } \\
\text { cover, cap, etc. }\end{array}$ & 6 & 3 & 9 \\
\hline \multirow{7}{*}{$\begin{array}{l}\text { 4. What are the } \\
\text { advantages of } \\
\text { treating your water } \\
\text { with bleach? }\end{array}$} & Health & 41 & 35 & 76 \\
\hline & Kills bacteria/microbes & 18 & 17 & 35 \\
\hline & Cleans the water & 6 & 15 & 21 \\
\hline & $\begin{array}{l}\text { Kills small } \\
\text { animals/insects/worms }\end{array}$ & 7 & 6 & 13 \\
\hline & Cleans the stomach/body & 6 & 7 & 13 \\
\hline & Extra can be used for laundry & 4 & 3 & 7 \\
\hline & Improves taste & 1 & 3 & 4 \\
\hline \multirow{4}{*}{$\begin{array}{l}\text { 5. What are the } \\
\text { disadvantages of } \\
\text { treating your water } \\
\text { with bleach? }\end{array}$} & No disadvantages & 32 & 31 & 63 \\
\hline & Bad for the body & 10 & 12 & 22 \\
\hline & Bad taste & 6 & 5 & 11 \\
\hline & Lack of knowledge & 3 & 1 & 4 \\
\hline
\end{tabular}




\begin{tabular}{|c|c|c|c|c|}
\hline & Too expensive & 3 & 1 & 4 \\
\hline & Ineffective & 1 & 2 & 3 \\
\hline \multirow{3}{*}{$\begin{array}{l}\text { 6. (Do/Would) most } \\
\text { of the people you } \\
\text { know approve of } \\
\text { you treating your } \\
\text { water with bleach? }\end{array}$} & Yes & 34 & 41 & 75 \\
\hline & Possibly & 11 & 9 & 20 \\
\hline & No & 1 & 1 & 2 \\
\hline \multirow{7}{*}{$\begin{array}{l}\text { 7. Who are the } \\
\text { people that } \\
\text { (approve/would } \\
\text { approve) of you } \\
\text { treating your water } \\
\text { with bleach? }\end{array}$} & Everyone & 23 & 25 & 48 \\
\hline & The household & 16 & 16 & 32 \\
\hline & Most People & 4 & 7 & 11 \\
\hline & $\begin{array}{l}\text { Those who "know" or "have } \\
\text { knowledge" }\end{array}$ & 4 & 5 & 9 \\
\hline & Husbands & 5 & 4 & 9 \\
\hline & Women & 4 & 4 & 8 \\
\hline & Health care workers & 3 & 1 & 4 \\
\hline \multirow{9}{*}{$\begin{array}{l}\text { 8. Who are the } \\
\text { people that } \\
\text { (disapprove/would } \\
\text { disapprove) of you } \\
\text { treating your water } \\
\text { with bleach? }\end{array}$} & No one & 27 & 19 & 46 \\
\hline & People who are not educated & 8 & 12 & 20 \\
\hline & Respondent didn't know & 7 & 8 & 15 \\
\hline & Some people & 3 & 7 & 10 \\
\hline & Old people & 2 & 4 & 6 \\
\hline & Men & 3 & 2 & 5 \\
\hline & Kids & 4 & 0 & 4 \\
\hline & People without money & 1 & 3 & 4 \\
\hline & Guests & 0 & 2 & 2 \\
\hline \multirow{3}{*}{$\begin{array}{l}\text { 9. How difficult is it } \\
\text { to get the materials } \\
\text { you need to treat } \\
\text { your water with } \\
\text { bleach? }\end{array}$} & Somewhat difficult & 15 & 21 & 36 \\
\hline & Not difficult at all & 19 & 13 & 32 \\
\hline & Very difficult & 12 & 16 & 28 \\
\hline \multirow{3}{*}{$\begin{array}{l}\text { 10. How difficult is } \\
\text { it to remember to } \\
\text { treat your water } \\
\text { with bleach? }\end{array}$} & Not difficult at all & 35 & 37 & 72 \\
\hline & Somewhat difficult & 8 & 10 & 18 \\
\hline & Very difficult & 3 & 4 & 7 \\
\hline \multirow{3}{*}{$\begin{array}{l}\text { 11. How likely is it } \\
\text { that you, your child, } \\
\text { or someone in your } \\
\text { family will get sick } \\
\text { from diarrhea in the } \\
\text { next three months? }\end{array}$} & Somewhat likely & 13 & 20 & 33 \\
\hline & Not likely at all & 19 & 13 & 32 \\
\hline & Very likely & 13 & 16 & 29 \\
\hline \multirow{2}{*}{$\begin{array}{l}\text { 12. How serious } \\
\text { would it be if you or } \\
\text { the children got }\end{array}$} & Very serious & 40 & 45 & 85 \\
\hline & Somewhat serious & 5 & 5 & 10 \\
\hline
\end{tabular}




\begin{tabular}{|c|c|c|c|c|}
\hline diarrhea? & Not serious at all & 0 & 1 & 1 \\
\hline \multirow{9}{*}{$\begin{array}{l}\text { 13. In your opinion, } \\
\text { what causes } \\
\text { diarrhea? }\end{array}$} & Bad/dirty water & 23 & 23 & 46 \\
\hline & Eating contaminated food & 18 & 19 & 37 \\
\hline & Personal dirtiness/bad hygiene & 18 & 15 & 33 \\
\hline & $\begin{array}{l}\text { Eating the wrong foods (too } \\
\text { much fruit or meat) }\end{array}$ & 8 & 7 & 15 \\
\hline & $\begin{array}{l}\text { Eating food that is bad (spoiled, } \\
\text { not cooked properly) }\end{array}$ & 7 & 8 & 15 \\
\hline & Respondent didn't know & 3 & 8 & 11 \\
\hline & Microbes & 6 & 5 & 11 \\
\hline & Bad stomach or illness & 4 & 3 & 7 \\
\hline & Eating dirt & 1 & 2 & 3 \\
\hline \multirow{3}{*}{$\begin{array}{l}\text { 14. How likely is it } \\
\text { that you or your } \\
\text { children would get } \\
\text { diarrhea if they } \\
\text { were to drink } \\
\text { untreated water? }\end{array}$} & Very likely & 32 & 29 & 61 \\
\hline & Somewhat likely & 13 & 15 & 28 \\
\hline & Not likely at all & 0 & 7 & 7 \\
\hline \multirow{3}{*}{$\begin{array}{l}\text { 15. Are there any } \\
\text { cultural rules or } \\
\text { taboos against } \\
\text { treating your } \\
\text { drinking water with } \\
\text { bleach? }\end{array}$} & No & 38 & 44 & 82 \\
\hline & Maybe & 4 & 4 & 8 \\
\hline & Yes & 4 & 3 & 7 \\
\hline \multirow{8}{*}{$\begin{array}{l}\text { 16. What is the one } \\
\text { thing you desire } \\
\text { most in life? }\end{array}$} & Health & 35 & 39 & 74 \\
\hline & Money & 12 & 16 & 28 \\
\hline & Peace & 11 & 6 & 17 \\
\hline & Livestock & 4 & 5 & 9 \\
\hline & $\begin{array}{l}\text { Material possessions (new hut, } \\
\text { mattress, etc) }\end{array}$ & 3 & 5 & 8 \\
\hline & Clean water & 2 & 6 & 8 \\
\hline & Knowledge & 6 & 0 & 6 \\
\hline & $\begin{array}{l}\text { Work for themselves and their } \\
\text { children }\end{array}$ & 0 & 2 & 2 \\
\hline
\end{tabular}


Table 6: Coliform colony count results for each individual. Counts displayed are the average \pm standard error. Bolded values were significant using a paired T-test between water at the point-of-use level (taken from the londe) and water at the source well.

\begin{tabular}{|c|c|c|c|c|}
\hline Community: & Dabo & Teyel & Sare Gueladio & Sare Meta \\
\hline $\begin{array}{l}\text { Sources of } \\
\text { Samples }\end{array}$ & $\begin{array}{l}\cdot 2 \text { Treater wells } \\
\cdot 2 \text { Treater londes } \\
\cdot 2 \text { Non-Treater wells } \\
\cdot 2 \text { Non-Treater } \\
\text { londes }\end{array}$ & $\begin{array}{l}\cdot 1 \text { Treater well } \\
\cdot 1 \text { Treater londe } \\
\cdot 3 \text { Non-Treater wells } \\
\text {-3 Non-Treater } \\
\text { londes }\end{array}$ & $\begin{array}{l}\cdot 2 \text { wells (used by all } \\
\text { respondents) } \\
.2 \text { Treater londes, } \\
\text {-4 Non-Treater } \\
\text { londes }\end{array}$ & $\begin{array}{l}\cdot 1 \text { well (used by } \\
\text { all } \\
\text { respondents) } \\
\cdot 2 \text { Treater } \\
\text { londes } \\
\cdot 3 \text { Non-Treater } \\
\text { londes }\end{array}$ \\
\hline \multirow[t]{2}{*}{ Treater Well(s) } & A) $13.33 \pm 0.33$ & \multirow[t]{2}{*}{$25.67 \pm 4.48$} & A) $6.33 \pm 1.76$ & \multirow[t]{2}{*}{$7.17 \pm 0.54$} \\
\hline & B) $19.67 \pm 3.28$ & & В) $47.67 \pm 8.25$ & \\
\hline \multirow[t]{2}{*}{ Treater Londe(s) } & A) $0.33 \pm 0.33$ & \multirow[t]{2}{*}{$0.20 \pm 0.20$} & $\begin{array}{l}\text { A) } 2.67 \pm 0.88 \text { (used } \\
\text { well A) }\end{array}$ & A) $0.00 \pm 0.00$ \\
\hline & B) $0.00 \pm 0.00$ & & $\begin{array}{l}\text { B) } 0.00 \pm 0.00 \text { (used } \\
\text { well } B \text { ) }\end{array}$ & B) $0.00 \pm 0.00$ \\
\hline \multirow{2}{*}{$\begin{array}{l}\text { Difference } \\
\text { between Treater } \\
\text { well(s) and treater } \\
\text { londe(s) (paired t- } \\
\text { test) }\end{array}$} & A) $t=38, p<0.001$ & \multirow[t]{2}{*}{$t=5.75, p=0.029$} & A) $t=1.41, p=0.294$ & $\begin{array}{l}\text { A) } t=13.21, \\
\text { D<0.001 }\end{array}$ \\
\hline & B) $t=5.99, p=0.027$ & & $\begin{array}{l}\text { B) } t=5.78 \\
p=0.029\end{array}$ & $\begin{array}{l}\text { B) } t=13.21 \\
\text { p }<0.001\end{array}$ \\
\hline \multirow[t]{3}{*}{ Non-treater wells } & A) $56.67 \pm 0.67$ & A) $17.33 \pm 1.33$ & A) $6.33 \pm 1.76$ & \multirow[t]{3}{*}{$7.17 \pm 0.54$} \\
\hline & \multirow[t]{2}{*}{ B) $0.00 \pm 0.00$} & B) $9 \pm 3.21$ & \multirow[t]{2}{*}{ В) $47.67 \pm 8.25$} & \\
\hline & & C) $26.5 \pm 0.65$ & & \\
\hline \multirow[t]{4}{*}{ Non-treater londes } & \multirow[t]{2}{*}{ A) $391 \pm 32.32$} & \multirow[t]{2}{*}{ A) $16 \pm 3.14$} & $\begin{array}{l}\text { A) } 494.33 \pm 9.40 \\
\text { (used well A) }\end{array}$ & \multirow[t]{2}{*}{ A) $17.33 \pm 2.19$} \\
\hline & & & $\begin{array}{l}\text { B) } 66.67 \pm 2.96 \text { (used } \\
\text { well A) }\end{array}$ & \\
\hline & \multirow[t]{2}{*}{ B) $0.67 \pm 0.33$} & B) $15 \pm 1.15$ & $\begin{array}{l}\text { C) } 49.67 \pm 8.65 \text { (used } \\
\text { well B) }\end{array}$ & B) $0.33 \pm 0.33$ \\
\hline & & C) $24.67 \pm 6.23$ & $\begin{array}{l}\text { D) } 39.33 \pm 8.69 \text { (used } \\
\text { well B) }\end{array}$ & C) $4.00 \pm 1.00$ \\
\hline \multirow{4}{*}{$\begin{array}{l}\text { Difference } \\
\text { between non- } \\
\text { treater well and } \\
\text { non-treater londes } \\
\text { (paired t-test) }\end{array}$} & \multirow[t]{2}{*}{ A) $t=10.38, p=0.009$} & \multirow[t]{2}{*}{ A) $t=0.61, p=0.604$} & A) $t=51.63, p<0.001$ & \multirow{2}{*}{$\begin{array}{l}\text { A) } t=3.97 \\
p=0.058\end{array}$} \\
\hline & & & B) $t=32.51, p<0.001$ & \\
\hline & \multirow[t]{2}{*}{$\begin{array}{l}\text { B) } t=2.00 \\
p=0.183503\end{array}$} & B) $t=1.38, p=0.303$ & C) $t=0.14, p=0.902$ & $\begin{array}{l}\text { B) } t=12.12 \\
p=0.007\end{array}$ \\
\hline & & C) $t=0.31, p=0.789$ & D) $t=0.62, p=0.600$ & $\begin{array}{l}\text { C) } t=3.78 \\
p=0.063\end{array}$ \\
\hline
\end{tabular}


Table 7: Escherichia coli colony count results for each individual. Counts displayed are the average \pm standard error. Bolded values were significant using a paired T-test between water at the point-of-use level (taken from the londe) and water at the source well.

\begin{tabular}{|c|c|c|c|c|}
\hline Community & Dabo & Teyel & Sare Gueladio & Sare Meta \\
\hline $\begin{array}{l}\text { Sources of } \\
\text { Samples }\end{array}$ & $\begin{array}{l}\cdot 2 \text { Treater wells } \\
\cdot 2 \text { Treater londes } \\
\cdot 2 \text { Non-Treater wells } \\
\text {-2 Non-Treater } \\
\text { londes }\end{array}$ & $\begin{array}{l}\cdot 1 \text { Treater well } \\
\cdot 1 \text { Treater londe } \\
\cdot 3 \text { Non-Treater wells } \\
\cdot 3 \text { Non-Treater } \\
\text { londes }\end{array}$ & $\begin{array}{l}\cdot 2 \text { wells (used by } \\
\text { all respondents) } \\
\cdot 2 \text { Treater londes, } \\
\text {-4 Non-Treater } \\
\text { londes }\end{array}$ & $\begin{array}{l}\text {-1 well (used by } \\
\text { all respondents) } \\
\text {-1 Treater londe } \\
\text {-3 Non-Treater } \\
\text { londes }\end{array}$ \\
\hline \multirow[t]{2}{*}{ Treater Well(s) } & A) $0.00 \pm 0.00$ & \multirow[t]{2}{*}{$0.33 \pm 0.33$} & A) $0.00 \pm 0.00$ & \multirow[t]{2}{*}{$0.17 \pm 0.17$} \\
\hline & B) $2.67 \pm 1.76$ & & B) $72.67 \pm 3.75$ & \\
\hline \multirow[t]{2}{*}{ Treater Londe(s) } & A) $0.00 \pm 0.00$ & \multirow[t]{2}{*}{$0.00 \pm 0.00$} & $\begin{array}{l}\text { A) } 0.33 \pm 0.33 \\
\text { (used well A) }\end{array}$ & A) $0.00 \pm 0.00$ \\
\hline & B) $0.00 \pm 0.00$ & & $\begin{array}{l}\text { B) } 0.00 \pm 0.00 \\
\text { (used well B) }\end{array}$ & B) $0.00 \pm 0.00$ \\
\hline \multirow{2}{*}{$\begin{array}{l}\text { Difference } \\
\text { between Treater } \\
\text { well(s) and treater } \\
\text { londe(s) (paired t- } \\
\text { test) }\end{array}$} & A) $t=1.51, p=0.270$ & \multirow[t]{2}{*}{$t=1.00, p=0.423$} & $t=1.00, p=0.423$ & $t=1.00, p=0.363$ \\
\hline & B) $N / A$ & & $t=19.34, p=0.003$ & $t=1.00, p=0.363$ \\
\hline \multirow[t]{3}{*}{ Non-treater wells } & A) $6.67 \pm 0.33$ & A) $1.00 \pm 1.00$ & A) $0.00 \pm 0.00$ & \multirow[t]{3}{*}{$0.17 \pm 0.17$} \\
\hline & \multirow[t]{2}{*}{ B) $1.33 \pm 0.88$} & B) $2.67 \pm 0.33$ & \multirow[t]{2}{*}{ B) $72.67 \pm 3.75$} & \\
\hline & & C) $7.67 \pm 1.45$ & & \\
\hline \multirow[t]{4}{*}{ Non-treater londes } & \multirow[t]{2}{*}{ A) $4.33 \pm 0.33$} & \multirow[t]{2}{*}{ A) $0.25 \pm 0.25$} & $\begin{array}{l}\text { A) } 0.00 \pm 0.00 \\
\text { (used well A) }\end{array}$ & \multirow[t]{2}{*}{ A) $0.00 \pm 0.00$} \\
\hline & & & $\begin{array}{l}\text { B) } 0.33 \pm 0.33 \\
\text { (used well A) }\end{array}$ & \\
\hline & \multirow[t]{2}{*}{ В) $1.67 \pm 0.88$} & B) $4.33 \pm 0.33$ & $\begin{array}{l}\text { C) } 32.67 \pm 0.88 \\
\text { (used well B) }\end{array}$ & B) $0.00 \pm 0.00$ \\
\hline & & C) $5.33 \pm 0.66$ & $\begin{array}{l}\text { D) } 67.67 \pm 19.06 \\
\text { (used well } B \text { ) }\end{array}$ & C) $0.00 \pm 0.00$ \\
\hline \multirow{4}{*}{$\begin{array}{l}\text { Difference } \\
\text { between non- } \\
\text { treater well and } \\
\text { non-treater londes } \\
\text { (paired t-test) }\end{array}$} & \multirow[t]{2}{*}{ A) $t=3.50, p=0.073$} & \multirow[t]{2}{*}{ A) $t=2.00, p=0.184$} & A) $t=0, p=1$ & \multirow{2}{*}{$\begin{array}{l}\text { A) } t=1.00 \\
p=0.363\end{array}$} \\
\hline & & & $\begin{array}{l}\text { B) } t=1.00 \\
p=0.423\end{array}$ & \\
\hline & \multirow[t]{2}{*}{ B) $t=0.38, p=0.742$} & B) $t=2.50, p=0.130$ & $\begin{array}{l}\text { C) } t=8.66 \text {, } \\
p=0.013\end{array}$ & $\begin{array}{l}\text { B) } t=1.00 \\
p=0.363\end{array}$ \\
\hline & & C) $t=1.15, p=0.369$ & $\begin{array}{l}\text { D) } t=0.32 \\
p=0.776\end{array}$ & $\begin{array}{l}\text { C) } t=1.00 \\
p=0.363\end{array}$ \\
\hline
\end{tabular}

